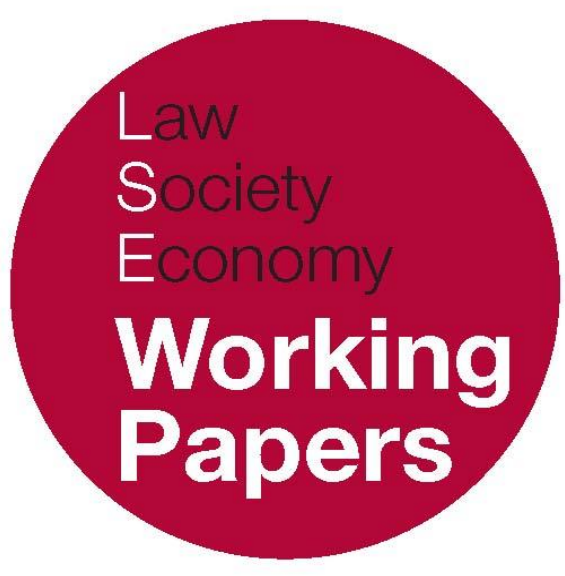

\title{
The Codetermination Bargains: \\ The History of German Corporate and Labour \\ Law
}

\author{
Ewan McGaughey \\ LSE Law, Society and Economy Working Papers 10/2015 \\ London School of Economics and Political Science \\ Law Department
}

This paper can be downloaded without charge from LSE Law, Society and Economy Working Papers at: www.lse.ac.uk/collections/law/wps/wps.htm and the Social Sciences Research Network electronic library at: http://ssrn.com/abstract $=2579932$.

(C) Ewan McGaughey. Users may download and/or print one copy to facilitate their private study or for non-commercial research. Users may not engage in further distribution of this material or use it for any profit-making activities or any other form of commercial gain. 


\title{
The Codetermination Bargains: The History of German Corporate and Labour Law
}

\author{
Ewan McGaughey *
}

\begin{abstract}
Why does codetermination exist in Germany? Law and economics theories have contended that if there were no legal compulsion, worker participation in corporate governance would be 'virtually nonexistent'. This positive analysis, which flows from the 'nexus of contracts' conception of the corporation, supports a normative argument that codetermination is inefficient because it is supposed that it will seldom happen voluntarily. After discussing competing conceptions of the corporation, as a 'thing in itself, and as an 'institution', this article explores the development of German codetermination from the mid$19^{\text {th }}$ century to the present. It finds the inefficiency argument sits at odds with the historical evidence. In its very inception, the right of workers to vote for a company board of directors, or in work councils with a voice in dismissals, came from collective agreements. It was not compelled by law, but was collectively bargained between business and labour representatives. These 'codetermination bargains' were widespread. Laws then codified these models. This was true at the foundation of the Weimar Republic from 1918 to 1922 and, after abolition in 1933, again from 1945 to 1951 . The foundational codetermination bargains were made because of two 'Goldilocks' conditions (conditions that were 'just right') which were not always seen in countries like the UK or US. First, inequality of bargaining power between workers and employers was temporarily less pronounced. Second, the trade union movement became united in the objective of seeking worker voice in corporate governance. As the practice of codetermination has been embraced by a majority of EU countries, and continues to spread, it is important to have an accurate positive narrative of codetermination's economic and political foundations.
\end{abstract}

\footnotetext{
* King's College, London and PhD Candidate, London School of Economics. Please send any comments to ewan.mcgaughey@,kcl.ac.uk. For help in substantive historical aspects, my especial thanks to Wolfgang Schneider and Hans Jürgen Teuteberg.
} 


\section{INTRODUCTION}

Conventional wisdom in corporate governance suggests worker participation only exists because of laws that probably harm the economy. In 1979, Michael Jensen and William Meckling memorably wrote that without 'fiat codetermination would be virtually nonexistent', that 'this system seldom arises out of voluntary arrangements', and this suggests it is 'less efficient than the alternatives which grow up and survive in a competitive environment'. ${ }^{1}$ If it was not to be held unconstitutional, Jensen and Meckling went on to say that codetermination could survive in Germany by becoming irrelevant, as shareholder interests bypassed the employee members of the supervisory board (Aufsichtsrat) and dealt directly with the executive (Vorstand). Alternatively, Germany's economy would grind to a halt like in Marshall Tito's Yugoslavia. ${ }^{2}$ As it happened, neither of these predictions came true. Codetermination does have significant effects and there is no sign of economic Balkanisation. However, it is still common to read (admittedly more in English language discourse) that shareholder control 'arises endogenously', ${ }^{3}$ that codetermination would not exist without a law, ${ }^{4}$ and that because of this worker voice entails 'governance externalities'. ${ }^{5}$ The trouble is, these views rest on a mistaken historical premise.

This article explains how German codetermination arose through collective agreements, which only subsequently were codified by the law. The 'codetermination bargains' is a name that signifies the collective agreements between business and trade unions from 1918, and then from 1945 to 1951 to establish work councils and give workers a vote for directors on company boards. ${ }^{6}$ These agreements were not the product of 'fiat'. They were made voluntarily. They were widespread. Consensual agreements paved the way to social consensus, and then the consensus was codified in law.

The timing of these developments is significant. In those historical moments where the codetermination bargains were made, two 'Goldilocks' conditions were met: conditions that were 'just right', ${ }^{7}$ but were not always mirrored abroad. First, the bargaining power between employers and employees had become relatively

\footnotetext{
${ }^{1}$ MC Jensen and W Meckling, 'Rights and Production Functions: An Application to Labor-Managed Firms and Codetermination' (1979) 52(4) Journal of Business 469, 473: 'The fact that this system seldom arises out of voluntary arrangements among individuals strongly suggests that codetermination or industrial democracy is less efficient than the alternatives which grow up and survive in a competitive environment [...]'.

2 Jensen and Meckling (1979) 52(4) Journal of Business 469, 503-504.

3 OE Williamson, The Economic Institutions of Capitalism (1985) 306.

${ }^{4} \mathrm{cf}$ B Cheffins, Company Law: Theory, Structure and Operation (1997) 583-5, reviewing relevant literature.

${ }^{5} \mathrm{~K}$ Pistor, 'Codetermination: A Sociopolitical Model with Governance Externalities', in M Blair and MJ Roe (eds), Employees and Corporate Governance (1999).

${ }^{6}$ Where employee representatives may bind what a board of directors could otherwise decide, albeit in specific spheres, this counts as much as 'codetermination' as being present on the board itself.

${ }^{7}$ For a fascinating account of Goldilocks and the Story of the Three Bears, see M Tatar, The Annotated Classic Fairy Tales (2002) 245-6. It points out that the way the ending of the story is told has changed over time.
} 
equal. With the collapse in political power and moral authority of business after both world wars, German trade unions were in a good position to bargain for codetermination. Second, the German labour movement had become unified around a common objective of getting a legally binding voice at work, in return for their investment of labour. They got it in collective agreements before it was written into statute. The labour movement's unity was not a given, because unions have always been committed to independence from management interests, to not be co-opted or dominated by the employer. ${ }^{8}$ The economic consensus that was reached formed the basis of the political consensus, which persists up to today.

Because there is good historical evidence for the 'codetermination bargain' view, it becomes much more difficult to argue that codetermination ought to be abandoned, or watered down, or avoided. Such proposals already have difficulty with political legitimacy, but they probably also lack legitimacy in economic terms. Empirical research has produced mixed conclusions about codetermination's economic efficiency. ' This reflects the politicised nature of the topic, and that studies sometimes find what they want to. ${ }^{10}$ Empirical research will not be dealt with here, but it is worth saying that in order to be meaningful, it must compare the consequences of codetermination with the consequences of shareholder monopolisation, assessed in reference to social goals like economic productivity and human development. But precisely while empirical findings remain mixed, it is very important for people who are sceptical of codetermination to retain a narrative that differs from what will be offered here.

Part 2 suggests that most analyses of codetermination and corporate governance align with one of three conceptions of the corporation: the Unternebmen an sich conception; the 'nexus of contracts' conception; or the conception of the corporation as an 'institution'. Only this third conception, properly understood, is truly comfortable with endorsing codetermination as a part of modern enterprise. This is because it sees the bargains of private actors as entailing power, which is exercised regardless of the legal forms of transactions. When the playing field is fair, it is a legitimate inspiration for legislation.

Part 3 explains the historical evolution of German codetermination. It starts with the inception of the legal ideal during the 1848 revolutions, it moves to the implementation of board codetermination from 1918 and its demise over the Weimar Republic, to its abolition by the fascist dictatorship, and to its resurrection after World War Two. German workers are now joined by workers in a majority

\footnotetext{
8 See also E McGaughey, 'British Codetermination and the Churchillian Circle' (2014) UCL LRI Working Paper 2/2014.

9 e.g. FR FitzRoy and K Kraft, 'Economic Effects of Codetermination' (1993) 95 Scandanavia Journal of Economics 365 and L Fauver and ME Fuerst, 'Does Good Corporate Governance Include Employee Representation? Evidence from German Corporate Boards' (2006) 82 Journal of Financial Economics 673.

10 Some of these problems can be avoided by being transparent about methodology and data. For the initial findings of possibly the most comprehensive quantitative study on labour relations, including representation at work, see J Armour, S Deakin, P Lele and M Siems, 'How Do Legal Rules Evolve? Evidence from a Cross-Country Comparison of Shareholder, Creditor, and Worker Protection' (2009) 57(3) American Journal of Comparative Law 579.
} 
of EU countries in the right to vote for the boss. There is also plenty of experience with codetermined institutions, especially in pensions, across the Commonwealth and the United States. As different countries serve as the laboratories of enterprise, as the numbers and knowledge of experiments spread, and as the democratisation of the economic realm endures, the historical narrative to explain it will matter more and more. ${ }^{11}$ History shows the better view is that codetermination is likely to stay, and that it remains a force for progress in corporate governance.

\section{THREE CONCEPTIONS OF THE CORPORATION}

Before exploring the evolution of German codetermination in detail, it makes sense to outline three competing conceptions of 'the corporation'. This is important because people have often thought of employees as external to what a corporation 'is'. 12 Conceptions subtly entail both positive and normative claims about the thing being conceived: though linguistically formulated as 'being', conceptions assert meaning. For instance, corporations might be thought as being owned and constituted by shareholders. ${ }^{13}$ Posed this way, labour's claims are demoted, as if an irritating conceptual transplant. In contrast, if a corporation is conceived as 'a combination of capital and labour', especially if capital derives from labour, ${ }^{14}$ then worker participation rights acquire absolute legitimacy. Simplistic oppositions of 'shareholders only' or 'capital and labour' were mostly, and thankfully, left behind in the $19^{\text {th }}$ century..$^{15}$ In the $20^{\text {th }}$ century, more sophisticated views looked not merely at the actors, but at the relativity of different actors' claims through the purposes of corporate governance. This indicated who should have a voice, and guided an understanding of how corporate power became shared.

\footnotetext{
11 Those who wish to focus on the essential historical evidence may refer directly to pages 22-23 and 3436. To assist in refuting the argument, they could also usefully consult A Schopenhauer, Die Kunst, Recht zu Behalten (1831).

${ }^{12}$ This ultimately traces back to the Roman view of a societas pecunia-opera, where to become a member one had to invest capital, and investing labour was not enough.

13 An example which seems to come close, but actually differs, is the best comparative corporate law text, R Kraakman, J Armour, P Davies, L Enriques, HB Hansmann, G Hertig, KJ Hopt, H Kanda, and EB Rock, The Anatomy of Corporate Law (2nd edn 2009) ch 2. This formulates the book's third agency problem as existing between shareholders and a corporation's 'other constituencies', often misinterpreted to be an agency problem between 'the company' and employees, or other groups.

14 See K Marx, Das Kapital (1894) vol 3, Part IV, ch 27, for Marx's views on the corporation. He invented the language of the separation of ownership and control, which was later adopted by Berle and Means. 15 At least in reputable academic discourse. In business, it is still common to hear the rhetoric of 'shareholder ownership' of the corporation. The term 'shareowner', which has become popular in the US, captures the legal position in a descriptively accurate ways, because shareholders own their shares, not the company.
} 


\section{(1) THE UNTERNEHMEN AN SICH}

The first main conception of a corporation is as a 'thing in itself': the Unternehmen an sich. ${ }^{16}$ Implicitly shareholder interests do not dominate, which potentially gives room for workers' claims, depending on what is seen as being in the autonomous 'interests of the company'. ${ }^{17}$ The German Federal Constitutional Court (Bundesverfassungsgericht) adopted this conception when finding that the Codetermination Act 1976 was constitutional. ${ }^{18}$ It originated in 1917 with Walter Rathenau, ${ }^{19}$ a liberal politician who had been a supervisory board director in his father's electronics company, AEG. Because the concession of the state creates a corporation, said Rathenau, shareholders' interests are not all-important. Shareholders are often irresponsible, ${ }^{20}$ while 'numerous' supervisory board directors give 'all their spare time freely and without special claims'. ${ }^{21}$ The Unternebmen an sich, run by benevolent directors, can be devoted to the 'public interest', in which workers count. Although shares were still capable of being privately owned and inherited, large corporations had acquired such economic importance that the corporation 'in itself had inevitably adopted a public character. ${ }^{22}$

Many difficulties of Rathenau's theory are well known, ${ }^{23}$ but they held a basic appeal for those seeking a fairer economy. In 1926, John Maynard Keynes told a gathering at the University of Berlin that a large corporation did indeed have a tendency to 'socialise itself. ${ }^{24}$ An accomplished debater, Keynes almost certainly knew that if something carries an air of inevitability, this may persuade an audience. In retrospect Keynes was plainly wrong, because private corporations did not spontaneously order social improvement. Moreover, there was no particular reason why Rathenau should have singled out a corporation as having a special 'public' status, just because it arises through a 'concession' of the state. Every contract depends for ultimate enforcement on public law institutions, namely tax-funded courts. This is seen to legitimise society declining to enforce terms that it perceives to be unjust. ${ }^{25}$ Arguing that corporations had shifted from

\footnotetext{
16 The word 'Unternehmen' translates equally well as 'enterprise' (as it is used, for instance, in EU competition law) but was meant by Rathenau to mean the narrower sense of 'corporation'.

17 Known as the 'Unternehmensinteresse'. Also, interpreted in this way by M Roth, 'Labor and Comparative Corporate Governance in times of Pension Capitalism' (2013) 18 Fordham Journal of Corporate and Financial Law 751, 785.

18 Bundesverfassungsgericht (1 March 1979) BVerfGE 50, 290, 315-6. It went on to say this meant there was no violation of the right to property.

19 cf O Gierke, Die soziale Aufgabe des Privatrechts (1889) whose work led in the personification of associations, as really existing 'things'.

${ }^{20}$ W Rathenau, Vom Aktienwesen: eine geschäftliche Betracbtung (1917) 32-33.

${ }^{21}$ Rathenau (1917) 17.

22 Rathenau (1917) 38-39.

${ }^{23}$ F Haussman, Vom Aktienwesen und Aktienrecht (1928) and see the excellent review of Rathenau and subsequent debate by M Gelter, 'Taming or Protecting the Modern Corporation? ShareholderStakeholder Debates in a Comparative Light' (2010) Working Paper N.165/2010, 42-57.

${ }^{24}$ JM Keynes, 'The End of Laissez Faire' (1926) Lecture at the University of Berlin. cf Rathenau (1917) 8.

25 O Gierke, Die Soziale Aufgabe des Privatrechts (1889) 14. JS Mill, Principles of Political Economy (1848) Book

$\mathrm{V}$, ch $1, \$ 2$, 'governments do not limit their concern with contracts to a simple enforcement. They take
} 
an abstract realm of 'private' to 'public' was simply unnecessary to justify regulation. It had more value as a rhetorical assertion.

In fact, Rathenau himself envisaged a different tendency in the actual development of corporations, akin to an 'iron law of oligarchy'. ${ }^{26}$ Rathenau thought the participation of shareholders in governance would gradually but inevitably give way to the stewardship of directors. ${ }^{27}$ German corporations did develop in this way, but very differently compared to Rathenau's benevolent expectations. Over the 1920s, the supervisory board's powers were inflated, they were packed with bank representatives, and shareholder voting rights were increasingly appropriated by management. By 1925, just one-fortieth of German capital accounted for a staggering 38.2 per cent of shareholder voting rights, ${ }^{28}$ concentrating power even beyond the extent seen in the US during the same time. ${ }^{29}$ But did the 'interests of the company' align with the public? No. Directors collected board seats like boys collecting stamps, gave themselves superinflationary pay rises, and focused on acquiring ever more power. ${ }^{30}$ The better view today has become that there is in fact no such thing as the company as such, no Ding an sich, only the applicable rules'. ${ }^{31}$ And unconstrained by rules, pursued to its logical conclusion, the conception of the Unternebmen an sich collapsed under the weight of its own ambiguity into the interests of directors. The worst of all worlds, it allowed a self-obsessed interest group to be enriched at everyone else's expense. ${ }^{32}$

\section{(2) NEXUS OF CONTRACTS}

In conscious opposition to the Unternebmen an sich, the conception developed that a corporation is nothing more than a legal fiction concealing a nexus of contractual

\footnotetext{
upon themselves to determine what contracts are fit to be enforced.' R Hale, 'Coercion and Distribution in a Supposedly Non-Coercive State' (1923) 38 Political Science Quarterly 472. R Hale, 'Bargaining, Duress and Economic Liberty' (1943) 43 Columbia Law Review 625.

${ }^{26}$ cf R Michels, Zur Soziologie des Parteiwesens in der modernen Demokratie: Untersuchungen über die oligarchischen Tendenzen des Gruppenlebens (1909) known as Political Parties in English. Michels posited, perfectly undeterred by intellectual rigour, that trade unions and social democratic parties had a tendency to degenerate into oligarchies. Originally a 'syndicalist' and pupil of Max Weber, he became disillusioned that a general strike did not take down government, migrated from Germany to Italy, joined Mussolini's fascist party, and became an economist. For an alternative theory, based on evidence, the Webbs identified a tendency for people to take conscious action within unions resulting in an uneasy balance but one that favours internal accountability, see S Webb and B Webb, Industrial Democracy (1920) ch 1, 'Primitive Democracy', 27.

27 Rathenau (1917) 39, described further in F Neumann, Bebemoth (1941) 234. It would seem, for a different purpose, that Neumann also regards a tendency to monopolisation of capital as inherent, but it seems that better view is that any such tendencies are contingent upon the governance of corporations, and public regulation, at least in the general kind of private enterprise.

${ }^{28} \mathrm{R}$ Müller-Erzbach, Die Entartung des deutschen Aktienwesens seit der Inflationszeit (1926) $11 \mathrm{ff}$.

${ }^{29}$ See AA Berle and GC Means, The Modern Corporation and Private Property (1932) 98-102.

${ }^{30}$ See part 3(3) below on 'that second collective agreement'.

31 Meridian Global Funds Management Asia Ltd v Securities Commission [1995] 2 AC 500, 507, per Lord Hoffmann at [10].

32 Berle and Means (1932) 310-312.
} 
relations. In 1934 a researcher for the German Bankers' Association, and a student of Berlin and Harvard named Johannes C. D. Zahn, wrote that the US economy had become strong because its corporate law followed two principles. ${ }^{33}$ First, the 'leadership principle' entailed directors having significant autonomy over governance. Second, a corporation was to be seen as 'a bundle of contractual relationships, between the corporation and the state, between directors and shareholders, between shareholders mutually'. ${ }^{34}$ On this view, the contracts by which people initially relate to a corporation are elevated beyond the legal concept, to the status of an ethical principle. All parties contracting through the corporation were to be regarded as equal, except for the leadership, because of its special role in guiding the enterprise. ${ }^{35}$ Multiple constituencies could not be represented because 'division in the leadership engenders the seeds of corporate weakness'. ${ }^{36}$ Zahn's objective, largely achieved in the Aktiengesetz. 1937,37 was to reinvent the corporation to conform with fascist ideology. ${ }^{38}$ This view was wholly incompatible with codetermination, just as it initially was with meaningful shareholder rights, or rights for any stakeholder except directors.

The nexus of contracts conception evolved in a number of ways, and partially broke with its fascist roots. Jensen and Meckling developed the view that the role of corporate law was to solve the principal-agent problem existing between various contracting parties, but especially shareholders and directors. ${ }^{39}$ While Zahn

33 JCD Zahn, Wirtschaftsfübrertum und Vertragsetbik im Neuen Aktienrecht (1934) 18-19. The title translates as Economic Leadership and Contractual Ethics in the New Corporate Law.

${ }^{34}$ F Kessler, 'Book Review: Wirtschaftsfihbrertum und Vertragsethik im Neuen Aktienrecht (1935) 83 University of Pennsylvania Law Review 393, 395.

35 Zahn (1934) 95, Wenn sich zwischen Vorstand und Aktionären ein echtes Führer-GeführtenVerhältnis entwickelt, wird das Stimmrecht des Aktionärs sehr an Bedeutung verlieren. Zunächst einmal wird der Aktionär viel weniger zu sagen haben, als bisher. Er wird dies aber gar nicht als ein Opfer empfinden, da er der Führung vertraut.' 'When a genuine leader-follower relationship develops between the executive and shareholders, shareholder voting rights will lose virtually all meaning. The shareholder will have much less to say than before. But he will not feel himself to be a victim, because he will trust the leader.'

${ }^{36}$ Zahn (1934) 15, 'Sie haben dabei richtig erkannt, daß es im gewerblichen Leben entscheidend auf die führernde Einzelpersönlichkeit ankommt und daß man mit der Zersplitterung der Leitung den Keim der Schwäche in ein Unternehmen hineinliegt.' Referring to American business, 'They have rightly recognised that in business life, that the personality of the leader is decisive and that any division of the leadership carries the seed of corporate weakness.'

37 W Schubert, 'Einleitung' in W Schubert, W Schmid and J Regge (eds), Akademie für Deutsches Recht 19331945: Protokolle der Ausschüsse (1986) Band I (Ausschuss für Aktienrecht) xlvii, who says Ernst Geßler credited Zahn as the leading inspiration for the shape of the Aktiengesetz 1937 regarding director election rules and shareholder voting rights. See also J von Hein, 'Vom Verstandsvorsitzenden zum CEO?' (2002) 166 ZHR 464, 476.

38 Zahn (1934) 11, 'Der Sieg der nationalen Revolution hat dieser Erörterung neuen Auftrieb und zum Teil eine andere Richtung gegeben'. 'The triumph of the national revolution has brought a new impetus and in part a different direction to this discussion'. At 93, 'Für die deutsche Aktienrechtsreform ist eine Untersuchung des Verhältnisses von Leitung und Aktionär in der corporation von höchsten Interesse. Die Entwicklung drängt dahin, die Herrschaft der Generalversammlung in der bisherigen Form zu beseitigen. Die Demokratie des Kapitals wird ebenso verschwinden wie die politische.' 'For German corporate law reform, an investigation of the relationship between the leadership and shareholders is of the highest interest. Its development compels that the dominance of the general meeting of shareholders in its contemporary form is to be eradicated. Democracy of capital is to disappear as it did in politics.'

${ }^{39}$ MC Jensen and W Meckling, 'Theory of the Firm: Managerial Behavior, Agency Costs and Ownership Structure' (1976) 3 Journal of Financial Economics 305. 
had receded, like the Dr Strangelove of corporate law, from academia to be a partner of Germany's largest private bank, ${ }^{40}$ Jensen and Meckling extended the nexus of contracts to include relationships with employees, creditors and others, and conceptualised 'contracts' as economic relations generating expectations even if not legally binding. ${ }^{41}$ Shareholders, however, were regarded as bearing a unique investment risk. In this way, they converted the nexus of contracts from a director to a shareholder primacy model of corporate governance. Frank Easterbrook and Daniel Fischel also promoted shareholder primacy in a nexus of contracts, rationalising shareholders' monopoly on voting rights with the idea that shareholders bear the residual risk of corporate insolvency.42 More recently, however, Stephen Bainbridge has re-married the nexus of contracts conception to director primacy. ${ }^{43}$ Significantly, these views now appear to have been adopted by the Republican appointees on the US Supreme Court. ${ }^{44}$ At no point has a nexus of contracts theorist envisaged 'labour primacy'. One could imagine using a labour theory of value to privilege workers' claims above others. ${ }^{45}$ But since the demise of the idea that workers hold any property in their work, ${ }^{46}$ and given the very emphasis on the nexus of contracts (not ownership inputs) that make up a firm, this option was always foreclosed.

40 Namely the Düsseldorfer C. G. Trinkaus-Bank. See the creepily sycophantic interview in 'Bankenfusion: Chef Kocht Selbst' (3 January 1972) Der Spiegel. Zahn's younger brother, Joachim, became the CEO of the car company, Daimler.

${ }^{41}$ This is not to suggest that Jensen and Meckling or the other authors drew conscious inspiration from Zahn's work.

${ }^{42}$ F Easterbrook and D Fischel, 'Voting in Corporate Law' (1983) 26(2) Journal of Law and Economics 395, 403.

43 S Bainbridge, 'Director Primacy and Shareholder Disempowerment' (2006) 119(6) Harvard Law Review 1735, 1746. To support his views Bainbridge happens to rely very similar cases to Zahn (1934) 91, particularly Manson v Curtis, 223 NY 313 (1918). This stands for the proposition that the board should remain accountable to multiple shareholders, and not be dominated by one, whereas Zahn and Bainbridge concluded it means the board should not be accountable.

${ }^{44}$ Burwell v Hobby Lobby Stores, Inc., 573 US (2014) at page 18, per Alito J, 'it is important to keep in mind that the purpose of this fiction is to provide protection for human beings. A corporation is simply a form of organization used by human beings to achieve desired ends. An established body of law specifies the rights and obligations of the people (including shareholders, officers, and employees) who are associated with a corporation in one way or another'. See also Scalia J in oral argument, page 53 of the transcript or 52:30 in the recording, speaking on favour of: 'Whoever controls the corporation.' Citizens United $v$ Federal Election Commission, 558 US (2010) page 8 of concurrence, referring to people giving up their rights to 'the leadership'. This is not to suggest US Supreme Court members are consciously pursuing any particular ideology. See O Kahn-Freund, 'Autobiographische Errinerungen an die Weimarer Republik. Ein Gespräch mit Wolfgang Luthardt' [1978] Kritische Justiz 183, 194, 'Ich habe in der Arbeit einen großer Fehler gemacht. Ich habe nämlich - um einmal Ihren Ausdruck zu benutzen - das politische Selbstverständnis der Richter überschätzt.' Kahn-Freund, speaking in 1978 of his famous 1931 article on the German courts' pursuit of a fascist social ideal, says, 'I made a great mistake in that work. Namely to use one of their expressions - I overestimated the political self-awareness of the judges.'

45 cf J Locke, Second Treatise of Government (1689) ch 5.

46 cf W Njoya, Property at Work (2007) which argues for this idea being revitalised so far as it would extend to rights such as job security and worker participation, rather than a market in buying and selling one's job. 
The nexus of contracts conception carries an intuitively appealing critique of the 'reification' or 'anthropomorphisation' of a corporation. ${ }^{47}$ Yet it dismisses one fiction only to replace it with another. ${ }^{48}$ Why is a contract any less of a 'fiction' than a corporation? In the legal mind, a contract generally arises when the social facts of offer, acceptance, and some quid pro quo, are exchanged in legally colourable contexts. In the economic mind, it is generated through the creation of reasonable expectations. ${ }^{49}$ Documents may evidence these social facts, but the same goes for an entry on the companies register. A contract is just as much a fiction as any abstraction, and so one might as well have called a corporation a 'nexus of fictions'. This does not advance the analysis. On the contrary, assertions like Easterbrook and Fischel's that all stakeholders were 'contracting nonetheless', ${ }^{50}$ or the idea that there is a common theory applicable to all contract types,${ }^{51}$ obscures economically and socially significant differences among different contracting parties. Why should commercial banks be viewed no differently to employees? Why should an asset management conglomerate be considered the same as a pensioner saving for retirement? How, except in the most superficial sense, is a multinational supplier the same as a consumer? ${ }^{52}$ In the end the normative claims of the nexus of contracts conception, like the value of oligarchical leadership or the superior moral significance of shareholder risk, are undermined by its own reliance on fictions.

\section{(3) CORPORATIONS AS INSTITUTIONS}

The third conception of a corporation as an institution abandons abstraction in appeal to social and economic reality. ${ }^{53}$ Corporations are 'instituted' by people in the sense that they must be positively created by different people's contributions. ${ }^{54}$ They are not simply conjured into existence by the hand of the state, nor does one group dominate in corporate governance because of a process of endogenous economic logic. Because people's burdens and risks in a corporation differ, so should their benefits and their claims. Pure assertion does not make unequal parties equal. Social position, economic wealth and bargaining power of different

\footnotetext{
$47 \mathrm{~J}$ Armour and C Mitchell, 'Companies and other associations' in A Burrows (ed), English Private Law (2013) ch 2.

48 See O Kahn-Freund, 'Hugo Sinzheimer 1875-1945' in Labour Law and Politics in the Weimar Republic (1981) 102 and F Neumann, Behemoth (1941) 366.

49 cf A Smith, Lectures on Justice, Police, Revenue and Arms (1763) Part I, Introduction and \$9. It is interesting how economic and legal conceptions usually converge.

50 FH Easterbrook and DR Fischel, 'The Corporate Contract' (1989) 89 Columbia Law Review 1416, 1429-1430.

51 OE Williamson, The Economic Institutions of Capitalism (1985) 241, 'A central thesis of this book is that a common theory of contract applies to transactions of all types - labor market transactions included. The organization of labor organization is nevertheless a very complicated matter.'

52 S Bainbridge, 'Participatory Management within a Theory of the Firm' (1996) 21 Journal of Corporate Law 657, 661, has said it is a metaphor and a useful heuristic rather than a positive account. But if this view is representative, then it just seems to be a misleading metaphor, and a bamboozling heuristic.

53 See F Neumann, Behemoth (1941) 366-8 and F Kessler, 'Book Review: Wirtschaftsführertum und Vertragsethik im Neuen Aktienrecht (1935) 83 University of Pennsylvania Law Review 393, 394.

54 See generally, G Renard, L'institution: fondement d'une renovation de l'ordre social (1931).
} 
parties, all mediated through a web of rules, are relevant to understanding corporations as institutions.

Unlike the nexus of contracts, the institutional conception has no difficulty in identifying who is 'inside' and 'outside' a corporation. ${ }^{55}$ The location of economic risk, which comes with the investment of capital or labour, ${ }^{56}$ is partly a product of different stakeholders' bargaining power, and this (as well as transaction costs ${ }^{57}$ ) determines a firm's boundaries. Shareholders do not have a privileged claim to governance rights over employees, because the risk of losing a job, or one's livelihood, is difficult to diversify. ${ }^{58}$ Most people who have jobs would think this 'job risk' has equal or weightier significance than a risk of falling share prices, because more people rely on their jobs than rely on shares. Moreover, today most shareholders are themselves institutions - not direct retail shareholders - who have appropriated shareholder rights with other people's money. These asset managers and banks bear no risk, nor make asset specific investments, as nexus of contracts theorists mistakenly profess. ${ }^{59}$

The legal tests to identify 'employees' have long understood enterprise (and thus the boundaries of the firm) through the institutional conception. 60 Institutional literature is concerned with transaction costs, ${ }^{61}$ but also with 'nontransaction costs': the costs which different actors have by not coming to an agreement. This depends on relative wealth, because if people risk going hungry by not getting a job, or a less dignified retirement if their savings are not invested, they have higher 'non-transaction costs' than those with ample resources. Less

\footnotetext{
55 cf O Hart and J Moore, 'Property Rights and the Nature of the Firm' (1990) 98(6) Journal of Political Economy 1119, who suggest the firm is defined by the ability to fire workers selectively. This argument is a logical cliffhanger, because the right to disassociate from a service provider depends on both sides' willingness, but this in turn depends on their bargaining power. Thus, the contractual rights of the parties merely reflect the economic reality (including wealth) of each. See further, R Hale, 'Bargaining, Duress and Economic Liberty' (1943) 43 Columbia Law Review 625.

56 A phrase gladly borrowed from R Goode, Principles of Corporate Insolvency (2009) 44.

57 cf RH Coase, 'The Nature of the Firm' (1937) 4(16) Economica 386. Coase's reduction of the firm to a question of transaction costs is therefore mistaken. It appears almost comically absurd when placed next to the work of the person who developed the transaction cost concept, and who knew all too well about the idea of bargaining power, JR Commons, 'Institutional Economics' (1931) 21 American Economic Review 648 and JR Commons and JB Andrews, Principles of Labor Legislation (Harper 1916) ch 1, 9.

${ }^{58}$ E Warren, 'Bankruptcy Policy' (1987) 54 University of Chicago Law Review 775.

${ }^{59} \mathrm{~F}$ Easterbrook and D Fischel, 'Voting in Corporate Law' (1983) 26 JLE 395, 403. OE Williamson, The Economic Institutions of Capitalism (1985) 314. SM Bainbridge, 'Participatory Management Within a Theory of the Firm' (1996) 21(4) Journal of Corporation Law 729.

${ }^{60}$ e.g. Pfeiffer v Deutsches Rotes Kreuz, Kreisverband Waldshut eV (2005) C-397/01, [2005] 1 CMLR 1123 and historically in Germany see Reichsarbeitsgerichtsentscheidung (15 Febraury 1930) Bensheimer Sammlung, vol 8, No 92, p 451, explored in O Kahn-Freund, 'The Social Ideal of the Reich Labour Court - A Critical Examination of the Practice of the Reich Labour Court' (1931) in O Kahn-Freund, R Lewis and J Clark (eds), Labour Law and Politics in the Weimar Republic (Social Science Research Council 1981) ch 3, 108, 143. For common law, see S Deakin and F Wilkinson, The Law of the Labour Market: Industrialization, Employment, and Legal Evolution (2005) ch 2, 'The Origins of the Contract of Employment'. The delineation of the firm is captured by Turberville v Stampe (1697) 91 ER 1072, Lord Holt CJ who, while discussing vicarious liability, says 'it shall be intended, that the servant had authority from his master, it being for the master's benefit.'

${ }^{61}$ On which, see JR Commons, 'Institutional Economics' (1931) 21 American Economic Review 648.
} 
wealth decreases the ability to 'hold out' in negotiations. ${ }^{62}$ Wealth inequality therefore exacerbates inequality of bargaining power, which in turn produces significant imbalances in transactional terms. This affects productive efficiency, because when people are getting an unfair deal they lose the motivation to work. ${ }^{63}$ The same is true when people can unjustly enrich themselves through their office, rather than by working. ${ }^{64}$ It follows that wealth inequality, and the inequality of bargaining power it produces, cannot be dismissed as an economic irrelevance. ${ }^{65}$ On the contrary, the institutional conception of the corporation actively acknowledges difference in people's economic and social status as it seeks to coordinate all stakeholders.

The main difficulty with the institutional conception (perhaps like all conceptions that boil down to a word or phrase) is it can be made to stand for opposing things. In particular, in The Economic Institutions of Capitalism, Oliver Williamson felt able to adopt the language of institutionalism, while simultaneously pledging fealty to the nexus of contracts conception, rejecting the existence or relevance of bargaining power, and opposing worker participation. ${ }^{66}$ This was said to be 'new' institutional economics, but the 'new' appeared so at odds with previous understandings that it was hard to see what was left of 'institutional' economics at all. 'New' institutionalism stripped away the social identity of the people that were fundamental to institutions in the first place. ${ }^{67}$

Simon Deakin has since elaborated a countervailing conception of the 'corporation as commons', ${ }^{68}$ following in the institutional tradition, and drawing on Elinor Ostrom's work on common pool resources. ${ }^{69}$ To Deakin, the corporation ought to be seen as a common pool resource, where multiple

\footnotetext{
${ }^{62}$ A Smith, An Inquiry into the Nature and Causes of the Wealth of Nations (1776) Book I, ch 8, \$12 and JR Commons and JB Andrews, Principles of Labor Legislation (Harper 1916) ch 1, 9.

${ }^{63}$ A Marshall, Principles of Economics (3rd edn 1895) Book VI, ch 4, 649, and A Cohn, E Fehr, B Herrmann and F Schneider, 'Social Comparison in the Workplace: Evidence from a Field Experiment' (2014) 12(4) Journal of the European Economic Association 877.

${ }^{64}$ AA Berle and GC Means, The Modern Corporation and Private Property (1932) 114.

65 cf RA Posner, 'Reflections on Consumerism' (1973) 20 University of Chicago Law School Record 19, 24-25, "The argument of "exploitation" based on "unequal bargaining power", however, lacks, so far as I can see, any economic basis.'

${ }^{66}$ OE Williamson, The Economic Institutions of Capitalism (1985) 237-258, especially.

${ }^{67}$ Another example is DC North, Institutions, Institutional Change and Economic Performance (1990) 5, saying 'The strength of micro-economic theory is that it is constructed on the basis of assumptions about individual human behavior [...]' and at 16, 'In a zero-transaction-cost world, bargaining strength does not affect the efficiency of outcomes'. This is fanciful because bargaining power affects the fairness of terms, and fairness affects the motivation to work, including in a zero-transaction-cost world. See E McGaughey, 'Behavioural Cconomics and Labour Law' (2014) LSE Law, Society and Economy Working Papers 20/2014.

68 S Deakin, 'The Corporation as Commons: Rethinking Property Rights, Governance and Sustainability in the Business Enterprise' (2011) 37 Queen's Law Journal 339.

69 e.g. E Schlager and E Ostrom, Property-Rights Regimes and Natural Resources: A Conceptual Analysis' (1992) 68(3) Land Economics 249. Ostrom received the Bank of Sweden Prize in Memorial of Alfred Nobel for 2009 jointly with Williamson. Their selection, even given their theoretical tensions in their work, seems to have been deliberate, and part of a developing tradition on the part of the Bank of Sweden's selection panel, of highlighting unreconciled ideological divides within the economics profession.
} 
constituencies stake claims to share in the product, and therefore its governance..$^{70}$ Of course, this does not suggest that all stakeholders have equal claims, as plainly some contribute more than others. Consumers of the occasional bag of pretzels do not contribute much but sporadic exchange, whereas consumers of a water company holding a natural monopoly do, because they are locked into an ongoing relationship by their unusual risk of finding no alternative supply. Just as the unity of the theory of contract could not be maintained, ${ }^{71}$ it is increasingly clear that there can be no unified theory of enterprise. The recognition that people have different needs in different circumstances means the corporation is not always just an economic, but also a 'social institution'. ${ }^{72}$ Whenever a stakeholding group stands in a weak bargaining position, the institutional conception recognises a claim to participation in governance. This may not hold true for consumers all the time, nor for all shareholders all of the time. But for employees the claim to participate in governance always holds.

Codetermination could only be genuinely compatible with the institutional conception of the firm. In the case of the Unternehmen an sich, codetermination may be tolerated, but the same conception is tolerant of an unrestricted right to manage: authoritarianism in stakeholder clothes. The nexus of contracts conception is actively hostile to worker participation, because with the fiction of contractual equality it attempts to eliminate the conceptual tools that distinguish different kinds of contractual relation. What do any of these approaches say about the actual evolution of corporate governance? The Unternebmen an sich suggests very little, but if anything, worker participation should only occur if the board views it as useful. The nexus of contracts idealists cannot see how codetermination would arise, except by legal 'intervention' in its imagined contractual construct. The institutional conception is dynamic, and does see a path for the evolution of corporate governance. It conceives of a way that the social power and economic circumstances of different actors will rise and fall, ebb and flow, in the channels of history. It is to this account that we now turn.

\footnotetext{
70 Deakin (2011) 37 Queen's Law Journal 339, 377-379.

${ }^{71}$ F Kessler, 'Contracts of Adhesion - Some Thoughts About Freedom of Contract' (1943) 43(5) Columbia Law Review 629, 636.

72 Notably L Strine, 'Toward Common Sense and Common Ground? Reflections on the Shared Interests of Managers and Labor in a More Rational System of Corporate Governance' (2007) 33 Journal of Corporate Law 1, 4. This is criticised by SM Bainbridge, 'The Shared Interests of Managers and Labor in Corporate Governance: A Comment on Strine' (2007) UCLA School of Law Public Law \& Legal Theory Research Paper Series Research Paper No. 07-15, who asks 'What does Strine mean when he calls the corporation a social institution?' It is not entirely clear if Bainbridge found an answer.
} 


\section{THE CODETERMINATION BARGAINS}

German codetermination was always part of a general movement for economic improvement. Culturally, it grew from the values of democracy, mutuality and solidarity that guilds and unions had promoted since the middle ages. ${ }^{73}$ Intellectually, the idea was first articulated by a Catholic theologian, called Franz von Baader during the $1830 \mathrm{~s},{ }^{74}$ and it had spread among those sympathetic to labour as a remedy for the depravation and dispossession of workers in the industrial revolution..$^{75}$ Legally, it began with the Spring of Nations, the Revolutions of March 1848, as the social instability of the German industrial revolution had culminated. ${ }^{76}$ Mechanised production in urban factories had outcompeted old work traditions, forcing people to search the cities for employment. Often the work they found was scarce, and by 1847 food shortages greeted the work shortages when over 200 riots broke out across the German Länder. For example, in the streets surrounding the Law Faculty of Berlin University three days of rioting at potato stalls and bakeries had to be quelled by the military. ${ }^{77}$ In February 1848, Germans received news that the French had launched a revolt and the month after they followed. It was still 60 years before the first codetermination bargains, but it was the critical starting point for the law.

\section{(1) PAULSKIRCHE AND PROHIBITION}

As the revolution spread, people assembled to demand a common, elected Parliament in the Paulskirche of Frankfurt. The Fürsten, princes and despots were startled enough that they let the vote happen. Among the new members of Parliament was a Saxon textile factory owner named Carl Degenkolb. His business was printed cloth (Kattundruck) which used the sort of machinery that had acutely affected pre-mechanical craft work. His industry had been notable before the March Revolution (or Vormärs) for the sprouts of participatory social institutions at work, particularly saving schemes or Kassen ${ }^{78}$ for sickness, death and

${ }^{73}$ HJ Teuteberg, Gescbicbte der Industriellen Mitbestimmung (1961) 118-119. Teuteberg's work, a History of Industrial Codetermination, remains the premiere historical treatment of German codetermination up to the year 1916.

${ }^{74}$ Franz von Baader is identified by HJ Teuteberg, Geschicbte der Industriellen Mitbestimmung in Deutschland (1961) $8 \mathrm{ff}$ as the first to affirm a legal claim for worker participation. See F Baader, Über den Mißverbältnis der Vermögenslosen oder Proletairs zu den Vermögen besitzenden Classen der Societät (1835) or On the Inequality between the Dispossessed or the Proletariat and the Propertied Classes of Society.

75 Immanuel Wohlwill, Robert von Mohl, Johannes Alois Perthaler and then the Centralverein für das Wohl der arbeitenden Klassen are further discussed by Teuteberg (1961) 19-58.

${ }^{76}$ EJ Hobsbawm, The Age of Capital 1848-1875 (1975) ch 1 and EJ Hobsbawm, The Age of Revolution 17891848 (1962) ch 16.

77 M Gailus, 'Foot Riots in Germany in the Late 1840s' (1994) 145 Past \& Present 164-167 and 184-185. The 'potato revolution' began at a stall in Gendarmenmarkt, after the lady who owned the stall raised her prices. She ran to seek refuge, around the back of the Berlin University's Law Faculty, to a bakery at 44 Charlottenstrasse (now the site of the Berlin State Library) which was also subsequently attacked and demolished by the rioters.

78 The author's translation of 'Kasse' as 'scheme' is not completely accurate. A literal translation is 'cache', but this hardly sits well in English. A better word is simply 'fund', but in 2002 a vehicle called a 
occasionally old age. ${ }^{79}$ Degenkolb had reached the view that workers, who otherwise had no substantial property to etch a living, needed to participate in the functioning of the economy as much as in political activity. ${ }^{80}$ Factories were not to be governed arbitrarily by an owner or employer, but by consent and by law. ${ }^{81}$

Over the Frankfurt Parliament's short span, Degenkolb allied himself to the majority liberal faction. ${ }^{82}$ On 24 May 1848 it convened an economic committee to propose a new business law. Degenkolb's ideas did not win majority support, but he and a minority still composed a draft, released on 12 January 1849. It would have required councils in every German business district to be composed of representatives chosen by factory committees, one third elected by workers, and two thirds the employer. ${ }^{83}$ The purpose was to circumscribe the absolute will of the employer in all workplace affairs, by setting out a list of five issues which the work councils could reach decisions: mediating disputes between employers and employees, drafting and enforcing specific factory ordinances (including to 'design regulations of the factory pension schemes and their administration'), administering the company health support schemes, monitoring child workers, and representing the factory in regional district councils. ${ }^{84}$ It was linked to a system of regional and national representation of workers in the country's economic affairs. ${ }^{85}$ It was also clear that because their voice comprised a third of votes workers would be outvoted on any issue, and that because council representation was indirect it would always be employer controlled. Nevertheless, this was the first law ever drafted for general worker participation in the economy. .86

By the summer of 1849 the German aristocracy came to its senses. In March it had seen the new constitution that the Paulskirche in Frankfurt wanted, with its unwelcome guarantees of civil and political rights. ${ }^{87}$ It pulled Parliamentary representatives back to the Länder, imprisoned or executed troublesome opponents, and had military troops break up the rest. Before and after the Paulskirche failure, trade unions were unflinchingly suppressed. The Prussian

Pensionsfond was created, and its legal distinction to a Pensionskasse means that we cannot use the word 'fund' twice for different things.

79 Teuteberg (1961) 164-175

80 HJ Teuteberg, 'Zur Entstehungsgeschichte der ersten betrieblichen Arbeitervertretungen in Deutschland' (1960) 11 Soziale Welt 69-82.

${ }^{81}$ C Degenkolb, Entwurf einer Fabrik-Gewerbe-Ordnung. Dem Volkswirtschaftlichen Ausschusse von seinem Mitgliede Degenkolb (1848) $10 \mathrm{ff}$. This is found in CD Haßler, Verhandlungen der deutschen verfassungsgebenden Reichsversammlung zu Frankfurt am Main (1848-1849) Band 2, 921 ff, as it is reproduced by Teuteberg (1961) 109.

82 Known as the Casino-Fraktion. The name derived from the name of their meeting hall, rather than any gambling tendencies.

83 Entwurf $1848 \int 42$

${ }^{84}$ Entwurf einer Gewerbeordnung für das deutsche Reich 1849 \$S43-5 (Draft Business Ordinance for the German Empire 1849).

85 Teuteberg (1961) 109-111 and Teuteberg (1960) 11(1-2) Soziale Welt 69, 77-78.

86 Teuteberg (1961) 111, 'eines der bedeutendsten Dokumente in der Geschichte der deutschen Mitbestimmung' or 'one of the most significant documents in the history of German codetermination.'

87 Paulskirchenverfassung or Verfassung des deutschen Reiches (28 March 1849). 
Gesetzessammlung 1845 (Consolidated Acts 1845) article 182 had stated 'formation of associations by factory hands, journeymen, trainees or apprentices without police permission is punishable by fines of 50 Talers or up to four weeks imprisonment', unless a stricter penalty was set out in law. 88 The Paulskirche constitution had included freedom of association, and so implicitly the right for trade unions to form to seek collective agreements or take collective action. 89 Following the post-Paulskirche wave of repression, the Prussian Vereinsgesetz 1850 (Association Act 1850) seemed to signal reconciliation and guarantee the same. ${ }^{90}$ But soon enough, a Federal Decision in 1854 clarified the freedom was inapplicable to worker associations with 'political, socialist or communist aims'. ${ }^{91}$ This meant that, while the first general company laws were passed in the Allgemeine Deutsche Handelsgesetzbuch 1861 (General German Commercial Code 1861), workers remained wholly disabled from seeking a greater voice: that would be 'political'. Strikes took place anyway, and after a wave of them in 1867, permanent union associations began to take shape. ${ }^{92}$ In 1869 a new North German Confederation Act apparently guaranteed freedom of association, except for farm, transport and government workers, but it excluded the right to take strike action. ${ }^{93}$

If collective action by workers was suppressed, the only source for employee participation at work could be employers themselves, or the law. Degenkolb had returned quietly to his Saxon business, but he was determined to implement his proposals personally. With three like-minded industrialists in his area, ${ }^{94}$ Degenkolb agreed a business constitution, configured with only slight differences to the minority draft. ${ }^{95}$ The historian Hans Jürgen Teuteberg, in his exhaustive study of German codetermination before 1916, could apparently find no archival detail beyond the statute itself on how the plan played out practically, but believed it remained in force until Degenkolb passed away in $1862 .{ }^{96}$ These primeval roots of a participatory workplace, the most humble glimmer of an idea that was put into practice, was still very isolated where poverty was prevalent. Many other industrialists cared deeply for workers' welfare, and were improving. Some even

\footnotetext{
88 PGBl (1845) art 182 A 443. nb art 134 guaranteed 'freedom of contract' initially granted when peasants were liberated from their ties of feudal serfdom, on 9 October 1807. This was the same year that the Slave Trade Act 1807 was passed by the UK Parliament, the first of a series of acts gradually abolishing the trading of slaves throughout the British Empire.

${ }^{89}$ Verfassung des Deutschen Reiches (28 March 1849) \$59, 'Der Reichsgewalt steht es zu, unbeschadet des durch die Grundrechte gewährleisteten Rechte der freien Vereinigung und Versammlung, Reichsgesetze über das Associationswesen zu erlassen.' \$S161-162 contained the rights on both gathering and associations.

90 Verordnung vom Uten März 1850, A 443.

${ }^{91}$ Federal Decision (13 July 1854).

${ }_{92}$ M Schneider, A Brief History of the German Trade Unions (1989) ch 2

93 Gewerbeordnung 1869, Bundesgesetzblatt des Norddeutschen Bundes No 26 (21 June 1869) 281, $\int \widehat{S 152-153}$.

94 Teuteberg (1960) 11 Soziale Welt 69, 78, the four groups of owners and businesses were Carl Degenkolb who owned Bodemer \& Co.; Adolph Michael and CF Mitscherlich of Danneberg \& Sobn; Gustav Ehrenberg and Carl Richter of Ehrenberg \& Richter; and Jacob Bodemer Jr of Jacob Bodemer Jr.

95 Teuteberg (1960) 11 Soziale Welt 69, 79 extracts the relevant provisions.

${ }_{96}$ Teuteberg (1960) 11 Soziale Welt 69, 82, footnote 15. Teuteberg (1961) 212-221.
} 
sympathised with worker involvement. ${ }^{97}$ The small, slow start was far less of a problem for the idea in this, the world's first general codetermination plan, than the overwhelming challenge of another view.

The challenge was best represented by Alfred Krupp and his family. The Kruppian philosophy could well be summed up as a sincere display of obligation to the workforce, coupled with an absolute denial of workers' right to selfdetermination. 'No other great industrialist', wrote historian Wolf Schneider, 'esteemed the personal freedom of his workers so little and their material wellbeing so highly. ${ }^{98}$ Krupp had started a health care scheme by 1836, aptly evidenced by company account entries reading ' 26 Nov 1836, 2 Talers of punishment money donated to the sickness scheme'. ${ }^{99}$ A revised scheme for health and death benefits ran from 1853, which included worker voice of a sort. The statute provided that there would be six worker deputies elected to manage the scheme, but that Krupp himself had the same number of votes as a third of the workers, and that Krupp would be the scheme president. ${ }^{100}$ He could do anything that he liked.

While the workforce could not organise and take collective action, the moral case for social welfare programmes was stronger. Krupp continued to introduce various schemes as his business grew dramatically after the 1850s, with a bakery in 1858, housing from 1870, and subsidies for buying life insurance in 1877.101 But any sign of workforce dissent was punished. Already in 1848, the last of Krupp's eight original workers had been dismissed for 'signs of insubordination'. The company libraries prohibited literature of the Sozialdemokratische Arbeiterpartei (Social Democrat Workers Party) and even the Zentrumspartei (Centre Party). When strikes took place on the Ruhr in 1872, Krupp said it would be a personal affront if anyone joined, and immediately dismissed anyone tainted with social democracy. ${ }^{102}$ Everything he believed was summed up during a national election campaign on 15 March 1877, when Krupp wrote the following to his workers.

Despite repeated warnings, the spirit of social democracy seems to keep wanting to creep into a number of you. It is pernicious, and every reasonable person must attempt to fight it, the employee just as much as the employer $[\ldots]$. That which has been earned by an industrious, thrifty family, that which a generation has honestly acquired, is what the indolent, the capricious are trying to snatch, to make the incompetent and the capable equal $[\ldots]$. I must

\footnotetext{
${ }^{97}$ Teuteberg (1961) 199, provides a list of examples of participatory plans from the later $1^{\text {th }}$ century.

98 W Schneider, Essen - das Abenteuer einer Stadt (1963) 233, 'Kein anderer Anführer des Industriezeitalters hat die persönliche Freiheit seiner Arbeiter so gering- und ihr leibliches Wohl so hochgeachtet.'

99 Teuteberg (1961) 192.

100 Teuteberg (1961) 193.

${ }^{101}$ EC McCreary, 'Social Welfare and Business: The Krupp Welfare Program, 1860-191' (1968) 42(1) The Business History Review 24, 31-38.

102 McCreary (1968) 42(1) The Business History Review 24, 47-48.
} 
bear the losses of the business alone, and so the profits are also rightfully mine, because I have earned them with my strength and my diligence. ${ }^{103}$

The challenge to the Paulskirche principles, then, that Krupp represented was the view that only the owner of the business had any right to participate an owner 'must bear the losses'. The loss that workers might suffer when dismissed seemed irrelevant. Krupp's risk and 'diligence' led him to believe that he alone 'earned' every mark of profit, absolutely. While Degenkolb had been convinced that dispossessed workers needed participation or there would never be progress, Krupp saw his ownership of company property as requiring that all benefits of the worker's labour accrued to the business. The leader had sole discretion of how the proceeds would be distributed. A separate company scheme for retirement and pensions was offered from 1885. It was linked to the number of years of service, and to income. ${ }^{104}$ But on the Krupp view there would hardly be any more scope for participation there. Any pension money built up, under this tradition of thought, was like any other contractual benefit: workers only had a right to insofar as the owner allowed it.

There was little chance of improvement after Germany's first unification. Before unification in 1871, there was a trend among some states to offer political channels for worker voice, outside their workplace. Typically a council elected by workers was created that could express a view to the Ministry for the Interior on proposed laws. ${ }^{105}$ These were purely consultative, and criticised by labour as a sham from the start. 106

In 1878 the first Sozialistengesetz (Socialist Act) was passed at the insistence of the Bismarck government. ${ }^{107}$ On its introduction, Bismarck said he wanted to improve the lot of the workers, including an association for the purpose of improving the position of the workers, to obtain for the workers a larger share in the profits of industry and to reduce working hours as far as is feasible'. ${ }^{108}$ But workers themselves could not participate in this process. Article 1 banned any 'associations with the purpose of overthrowing the existing state and social order by working for social democratic, socialist or communist ideas'. This made the

\footnotetext{
103 Extracted by W Schneider, Essen - Abenteuer einer Stadt (Econ Verlag 1963, new edn 1978), 232, 'Trotz wiederholter Warnung scheint sich unter einem Theiler von Euch der Geist der Sozialdemokratie einschleichen zu wollen. Dieser Geist aber ist verderblich, und jeder Verständige muß ihn bekämpfen, der Arbeiter so gut wie der Arbeitgeber [...]. Was eine fleißige sparsame Familie, was eine Generation ehrlich erworben hat, soll der Faule, Liederliche sich aneignen dürfen und der Unfähige dem Tüchtigen gleich gestellt werden... Wie ich den Verlust allein tragen muß, so ist auch der Gewinn mein von Rechtswegen, denn ich habe ihn erworben mit meiner Kraft und meiner Sorge.'

104 EC McCreary (1968) 33-34. Originally linked to disability benefits, it was linked to wages and years worked, financed with $1 \%$ worker and $0.5 \%$ employer contributions. Office workers allowed in 1890, and in 1895 it was available for any worker over 65 or with 40 years' service.

105 Teuteberg (1961) 326-341.

106 AW Lette, 'Die Organisation der arbeitenden Klassen und die Gewerbeordnung vom 9. Februar 1849' in Mittheilungen des Centralvereins für das Wobl der arbeitenden Klassen (1849) 20-30.

107 Sozialistengesetz (19 October 1878) RGBl 34, 351-358. Long title: 'Law Against the Efforts of Social Democracy to Endanger Society.'

108 Otto von Bismarck (9 October 1878) quoted in Schneider (1989) 53.
} 
essential work of trade unions impossible, because they did indeed believe in overthrowing the existing state and social order: a despotic monarchy, unspeakable poverty, oppression of conscience and association. It was true that social democrats could act through politics, ${ }^{109}$ and seek election to the Reichstag. But then the upper house of Parliament, the Bundesrat, could veto anything. Members there were elected, according to three class voting system in most states, according to the taxes that people paid: wealthier people having more votes. This meant that the option for social democrats of doing anything once in Parliament was largely foreclosed.

The state had created another outlet of a kind. As part of Bismarck's welfare reforms, the Krankenversicherungsgesetz 1883 (Health Insurance Act 1883) required the managers of the new company health schemes, in firms of over 50 staff, to be elected by a general meeting where the workforce held two thirds of the votes and the employer up to one third. ${ }^{110}$ The reason for the Bismarck government to introduce this form of worker voice appeared to be down to the existing health, pension and other social schemes where employers had introduced some voice. Though limited to a single issue, this was probably the world's first statutory form of codetermination. ${ }^{111}$ Over 6000 schemes were created between 1883 and 1890, and continued to function well. 112

\section{(2) From CONSUltation to CODETERMination}

The most severe suppression of social democracy ended in 1890, when the Sozialistengesetz was left to expire, and Otto von Bismarck was forced out of the Chancellorship. In 1888, a younger Kaiser Wilhelm II had acceded to the throne. He became interested in social affairs, and in 1889 when a strike on the Rhine and the Westfalian coal fields began, he expressed sympathy with the miners' objectives. They wanted a rise in pay in line with the rising profits of the mine owners, but they also included another demand. A strike committee convened in Berlin on 15 May 1889, and apparently on the suggestion of the Berlin Liberal MP, Karl Baumbach, it was resolved that a compromise offer might be to introduce work councils with the right to participate on major economic changes to a business.

As Wilhelm II said he saw it, the breaches of contract by the workers on strike were worthy of reproach, but 'reasonable demands, if unheeded, turn into

\footnotetext{
109 Sozialistengesetz 1878, 'Meetings relating to an election for the Reichstag or the state legislature' exempted.

${ }^{110}$ Krankenversicherungsgesetz (15 June 1883) RGBl S. 73. \$\$34, 38 and 59-68.

111 However, perhaps surprisingly the first statutory form of employee codetermination on company boards belonged to the UK, either in the South Metropolitan Gas Act 1896 or the Port of London Act 1908. See E McGaughey, 'British codetermination and the Churchillian Circle' (2014) UCL LRI Working Paper 2/2014.

112 Teuteberg (1961) 362-363.
} 
unreasonable demands'. 113 And put simply, 'factory orders should no longer be issued unilaterally by enterprises, rather than be agreed with representatives of the workforce'. ${ }^{114}$ Bismarck seemed essentially opposed, but was weakening politically. He was defeated on 25 January 1890 in a vote in the Reichstag to renew the Sozialistengesetr. Wilhelm II drew up a work council plan along with Hans Hermann Freiherr von Berlepsch, Minister for Trade and Business from 31 January 1890. Their draft only envisaged an option for employers to set up work councils, and the intention was announced in a Decree by the Kaiser on 4 February. The moment proved ripe, because on 20 February, there was a general election. The Social Democrat Party emerged as the largest political party in Germany, although the voting system meant it had far fewer representatives than others in the Reichstag. ${ }^{115}$ This culmination of events meant that on March 18 Bismarck was forced to resign. The way was clear for reform.

The Arbeiterschutzgesetz 1891 (Worker Protection Act 1891) was the result.116 Amending the Gewerbeordnung 1883 (Business Ordinance 1883) it essentially introduced the provisions that Wilhelm II and Berlepsch had written. ${ }^{117}$ The essence was that under $\$ 134 \mathrm{~b}$, employers had a legal duty to issue workplace rules on four main issues: working times and breaks, the type and time of wage payment, notice periods and reasons for dismissals, and workplace punishments. Under $\$ 134 d$, employers had to let workers express a view, and an elected work council could be part of this. Naturally, this law did not appear much to representatives of workers. The Social Democrats opposed the law completely because according to August Bebel, it was a 'sham system [...] a sham constitutional fig leaf, trying to conceal factory feudalism'. ${ }^{118}$ He made it known the SPD was opposed to worker councils in general, and was entirely uninterested in alternative plans for involvement in management, where workers could always be outspoken.

Kaiser Wilhelm II, perhaps because he was still at an optimistic age of his early thirties, was surprised and impatient that the 1891 Act did not deliver quick results to the social landscape. ${ }^{119}$ There was also another specific Act, written in much the same way by Berlepsch, the Preussische Berggesetz 1892 (Prussian Mining Act 1892), but neither did this make much difference. ${ }^{120}$ Indeed, 1891 marked the

\footnotetext{
113 Teuteberg (1961) 373, 'berechtigte Forderungen, wenn sie nicht berücksichtigt werden, sich in unberechtigte verwandeln'.

114 Teuteberg (1961) 372, quoting Georg Freiherr von Eppstein (ed), Fürst Bismarcks Entlassung (1920) 149. DD218 E61.

115 The SPD received $7.5 \%$ of the vote in $1873,6.1 \%$ in $1881,9.7 \%$ in $1884,7.1 \%$ in $1887,19.7 \%$ in 1890. This produced only 35 seats, compared for example to the Zentrumspartei, with $18.6 \%$ of the vote and 106 seats.

116 Gesetz betreffend Abänderung der Gewerbeordnung (1 June 1891) RGB1 S. 261, \$\$134b and 134d.

117 Teuteberg (1961) 373 and 377-378. The Act's drafting is attributed to Theodor Lohmann and his assistants Dönhoff and von Meyeren.

118 Stenographische Berichte über die Verhandlungen des Deutschen Reichstages Session 1890/91, Band 3, S. 2323.

119 Teuteberg (1961) 400.

120 Allgemeines Berggesetz für die Preussischen Staaten (24 June 1892) inserting $\$ \int 80 \mathrm{a}$ to 80g into the former Berggesetz 1865.
} 
point where more and more workers joined the trade union movement, the alternative that work councils were meant to stall, in the more free conditions for collective action. For different reasons, the workforce appeared just as disillusioned with the 1891 Act. In some regions, particularly around Tübingen in Württemberg, there were employers who embraced work councils. But because the system remained voluntary, by 1905 take-up had stalled at an estimated 10 per cent of German firms with over 20 employees. ${ }^{121}$ Not even the apparent approval from Pope Leo XIII, who had released an encyclical on the rights and duties of capital and labour in 1891, changed the fact that the employer's natural interest was opposed.122 It seemed that, even if it might be better from a production viewpoint to have worker participation, employers would not seize the option if it was perceived as an effort, or it threatened any short term reduction of profits. And trade unions were not yet strong enough to force it.

But although disillusioned with the superficial involvement that work councils produced, the experience made union and SPD members believe in reconstructing the councils with real participation power, and to make them obligatory. In 1900, Bavaria took the state-wide step of requiring consultative work councils in all its mining companies with over 20 staff. ${ }^{123}$ Not content, in March of 1901, the miners' trade union called for compulsory councils across all mining companies. ${ }^{124}$ When a strike broke out in 1905, greater participation became a key demand. The workers' protest centred, among other things, upon the lack of health care, increases in working hours and pit closures. It first broke out at the mining company owned by Hugo Stinnes, described later as an inveterate enemy of democracy', ${ }^{125}$ and the strike spread until over 200,000 workers were involved. Employers refused to negotiate, but the Prussian state conceded that a political solution could be met. It launched an investigation and produced a new revision of the Preussische Berggesetz 1905 (Prussian Mining Act 1905).126 Under a new \80f, compulsory work councils would have the right to be heard on various workplace issues, where there were more than 100 employees. But the fact was, there were still no general participation rights yet. Workers could be heard, but ignored.

The coming of war changed this. Politically, the leadership SPD and many of the trade unions supported the government as the Schlieffen Plan went into action. Kaiser Wilhelm II, addressing the Reichstag, seemed to believe that in war he had found the suspension of class conflict he had wanted. 'Ich kenne keine Parteien mehr,' he said, 'ich kenne nur noch Deutsche.'127 But as war went onto

\footnotetext{
121 Teuteberg (1961) 402-408.

122 Pope Leo XIII, Rerum Novarum (15 May 1891). The Vatican's stance may have been influenced by Bismarck's Kulturkampf.

${ }^{123}$ Berggesetz 1900 \$\$87-88 and 91.

124 O Hue, Die Bergarbeiter (1913) Band 2, 540. HD 8039.M6 H88.

125 The blunt assessment of FL Neumann, Behemoth (1941) 22.

126 Gesetz, betreffend die Abänderung einzelner Bestimmungen des Allgemeinen Berggesetzes vom 24 Juni 1865/1892 (14 July 1905).

${ }_{127}$ 'I no longer see parties, I only see Germans.'
} 
the end of its first, and then its second, and then its third year, as Germans and French bled in the mud of Verdun, and the bombs rained into the Somme, and drove men to madness, something of that confidence was lost. By December of 1916, the Empire found it necessary to demand every man work. In one of its last Acts, in the Hilfsdienstgesetz 1916 (Auxillary Service Act 1916) forced labour was brought to the entire adult male population. ${ }^{128}$ The first draft had contained only four paragraphs, but revisions in Parliament expanded it to twenty. It was easy for social democrat politicians to introduce new demands, and they did, for compulsory work councils in workplaces with over 50 staff. ${ }^{129}$ But this time, it went further because instead of a right merely to be heard, $\$ 13$ required that if agreement was not reached, the employer could be taken to arbitration. Teuteberg has marked this as 'the end of the unilateral right to manage'. ${ }^{130}$ It was, apparently, 'the train of victory for the belief in the organisation'.131 But if the end of the unilateral right to manage came through a law, as Germany collapsed into revolution, as Wilhelm II was deposed, and the Empire crumbled, the beginning of modern German codetermination was different.

\section{(3) Two COLLECTIVE AGREEMENTS}

In early November 1918, the German army and people started a revolution that forced the war to a halt. On 9 November, the SPD leadership declared a Republic and Wilhelm II was compelled to abdicate. With an end to political imperialism, the question was what shape the economy would take. On 15 November 1918, the three largest unions met the employers' federations to conclude an agreement for a post-war Arbeitsgemeinschaft (Workplace Community). ${ }^{132}$ With Hugo Stinnes representing employers, ${ }^{133}$ and Carl Legien for the trade unions, they signed the most important collective agreement in history. The Stinnes-Legien Abkommen (Stinnes-Legien Agreement) had as its centrepiece in $\$ 1$ the 'common resolution of all economic and social questions in German industry and trade'. Employers promised to end restrictions on freedom of association, to disestablish sham unions and to accept work councils in companies with over 50 staff. ${ }^{134}$ In those respects it resembled its contemporaries in the UK Whitley Reports and the US National War Labor Board resolutions. Yet the promise of codetermination arrived, not as a law, not as a regulation, but as an agreement. The reason that

\footnotetext{
128 Gesetz uiber den vaterländischen Hilfsdienst (5 December 1916) RGBl S. 1333. \$1.

129 Antrag Spahn und Genossen (Drucksache Nr 532) and Antrag Albrecht und Genossen (Drucksache $\mathrm{Nr} 535)$.

130 Teuteberg (1961) 508 ff.

131 Gustav Stresemann, Stenographische Berichte über die Verhandlungen des Deutschen Reichstages, Legislaturperiode 1916/17, 2. Session, S. 2250.

132 This was enacted in law as the Tarifvertragsverordnung (23 December 1918) RGBl 1918, Nr 287, S 1456.

$133 \mathrm{nb}$ : other signatories happened to include Walter Rathenau and Carl Friedrich von Siemens.

134 See GD Feldman, 'German Business between War and Revolution On the Origins of the StinnesLegien Agreement' in GA Ritter, Entstehung und Wandel der modernen Gesellschaft: Festschrift fuir Hans Rosenberg zum 65. Geburtstag (1970).
} 
employers agreed was not because they were coerced or misinformed, or they suddenly realised that the social gains of worker participation in the economy would outweigh private costs. It was because at the end of the War their bargaining power, like the economy, lay in ruins.

Collective agreement did not mean an easy transition to cooperative action. Carl Legien himself, like August Bebel before him, had remained highly sceptical of spreading codetermination because he believed it might spell the end for the purpose of trade unions. ${ }^{135}$ There was also dissent within the SPD leadership, but when the new Chancellor Phillip Scheidemann denied that a system of councils might be written into the constitution, mass demonstrations and strikes were mounted by the existing council members. They won. In March 1919 at the SPD conference, a labour lawyer and elected member of the interim Weimar National Assembly named Hugo Sinzheimer proposed a text for a right of codetermination in general, and work councils in particular, and it was adopted. Sinzheimer piloted the draft through the constitutional committee, ${ }^{136}$ and from 11 August 1919 the Weimar Constitution took effect. ${ }^{137}$ Article 153 stated that 'property carries responsibility' and article 165 gave workers the promise of participation in the 'entire field of economic development', including 'legal representation in factory workers councils'.

The first of the 'Goldilocks conditions' was met after the War: the relative bargaining power of capital and labour had become more equal. But this would only translate into action on a second condition, that the labour movement was united. Labour representatives were uncertain till the end, but popular demand impelled them to action. This year was also the height of popular organisation. On 15 March 1920, the unions achieved a decisive victory in preserving the democratic process against the Kapp Putsch. ${ }^{138}$ Conservatives and imperialist generals, who blamed the weakness of domestic liberals for losing World War One, attempted a military coup. They pointed to the humiliating terms of the Versailles Treaty and drew support from soldiers undergoing compulsory demobilisation. When a military faction occupied Berlin, the Social Democrat government called on the unions to hold a general strike, and over 12 million workers (half as many workers again as were union members) participated. Support for the coup was dwarfed and it ended in four days. But soon after this, the Social Democrat leadership fell. Soon economic disaster struck as reparation

\footnotetext{
135 R Dukes, 'The Origins of the German System of Worker Representation' (2005) 19 Historical Studies in Industrial Relations 31, 42-45. This is by far the best contextual treatment in English on the period between 1914 and 1922.

136 K Kubo, Hugo Sinzheimer - Vater des deutschen Arbeitsrechts: eine Biographie (1995) 80-82.

137 The Weimar Constitution is generally seen to have been a political settlement that codified this along with three other agreements, understandings or coalitions, regarding demobilisation (Hindenberg-Ebert), settlement within the Social Democrats to include legal codetermination, dispansion of Prussia and equalisation of the states, and a Parliamentary coalition among Social Democrats, the Catholic Centre and the Democrats. See FL Neumann, Behemoth (1941) 19-21.

138 See GD Feldman, 'Big Business and the Kapp Putsch' (1971) 4(2) Central European History 99.
} 
payments could not be kept, ${ }^{139}$ and the Ruhr was occupied by French troops. The Centre led government decided to print money as a way out, and hyperinflation ensued. Whereas union membership numbers had soared over the revolution, in the economic chaos membership to drop by a half.

\section{Free trade union members 1891-2011}

Source: Deutsche Gewerkschaftsbund

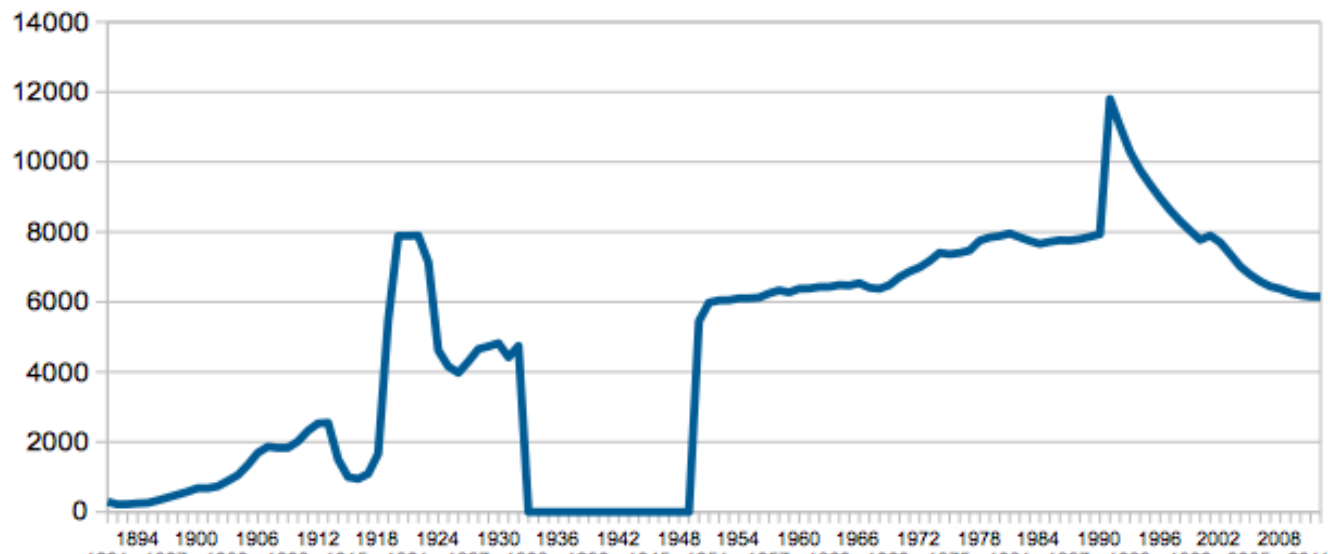

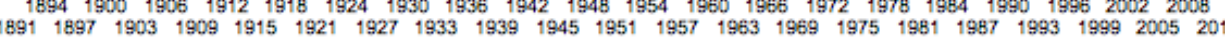

Free (socialist)

In the meantime, the question remained, how would the promises of the StinnesLegien Abkommen, and its codification in the constitution, be shaped into primary legislation? The first concrete manifestation was the Betriebsrätegesetz 1920 (Work Councils Act 1920). ${ }^{140}$ Its most important provisions were that, first, in businesses with over 20 employees elected work councils, ${ }^{141}$ had nine tasks under $\$ 66$. At least five of these were formulated more as duties: to promote the business' success, contribute to implementing new work methods, guarding against instability, promoting understanding between workers and employers, and representing the workforce's complaints. ${ }^{142}$ Two had more regulatory elements:

\footnotetext{
139 This was foreseen by JM Keynes, The Economic Consequences of the Peace (1919). The terms of Versailles drew a host of other critiques, including Adolf A. Berle, who had been working on the Wilson delegation. On this see Keynes' ch III, on the moral collapse of the President.

140 Betriebsrätegesetz 1920 (RGBl S 147, 4 February 1920). See E Frankel, 'The German Works Councils' (1923) 31(5) Journal of Political Economy 708. nb: I use the singular 'work council', maybe with an air of futility, but because 'works' mistranslates the genitive tense of 'Betriebs-' as a plural. Put another way literally, Betriebsräte means 'Councils of Work', or in a more comfortable English expression, work council.

141 Betriebsrätegesetz $1920 \$ 1$.

142 Betriebsrätegesetz $1920 \$ 66$ Nrs 1-3, 6 and 7.
} 
assisting in implementing arbitral awards and health and safety regulations. ${ }^{143}$ Two appeared as genuine codetermination rights: to agree common terms and conditions of service, and to join in the administration of pension schemes, housing and other social facilities. ${ }^{144}$

Second, in $\iint 84-87$ work councils gained the crucial, albeit negative, right of participating in dismissal decisions. Employees who were dismissed could appeal to the work council on grounds that they suffered gender, political, military, religious or union based discrimination, if dismissed without any reasons, or if it would cause significant hardship. The council could choose to take up the complaint to arbitration, and if the complaint were found justified compensation (but not reinstatement, yet) could be ordered. Third, in $\$ 70$, where the company had a supervisory council, there was a right for one or two work council representatives to be seated as fully equal members. This required a further implementing law, which after significant protest from newly assertive businesses that wished to renege, 145 succeeded in the Aufsichtsratgesetz 1922 (Supervisory Concil Act 1922). ${ }^{146}$ In $\$ 1$, the law applied across all corporate forms, and regardless of the company constitution's description of the supervisory council. Then $₫ 4$ required one employee representative, or two in supervisory councils with three directors or more.

Codetermination had been successfully codified, but its implementation over the Weimar Republic depended on the courts, and the continued strength of the unions to utilise it. To the judiciary of the Reichsgericht (still, anachronistically, named the 'Empire Court') it did not seem that the new social state was a particularly laudable aim. In 1923, under the leadership of Walter Simons, it expressed its view that the Weimar Constitution's article 165 was a provision that had a 'purely programmatic meaning', and so it did not create any actual legal rights. ${ }^{147}$ This was an extremely curious opinion, ${ }^{148}$ not least since Hugo Sinzheimer had written the provision, and believed it to have had legally binding effect. ${ }^{149}$ But the Reichsgericht continued to repeat its stance. ${ }^{150}$ In any event, business learned quickly to actively evade what they saw as the most threatening provisions, of employee representatives on the supervisory councils. There were three basic strategies. ${ }^{151}$ First, the functions allocated to supervisory councils (except appointments, on which workers would be outvoted anyway) were

\footnotetext{
143 Betriebsrätegesetz $1920 \$ 66 \mathrm{Nrs} 4$ and 8, though health and safety was also an area for common agreement.

${ }_{144}$ Betriebsrätegesetz $1920 \$ 66 \mathrm{Nrs} 5$ and 9.

145 G Flatow and O Kahn-Freund, Betriebsrätegesetz (13 th edn 1931) 356, $\$ 70$.

146 Gesetz über die Entsendung von Betriebsratsmitgliedern in den Aufsichtsrat (1 February 1922) RGB1. I, S. 209.

${ }_{147}$ RG (25 September 1923) RGZ 107, 245, 'nur programmatische Bedeutung'.

148 For members of the non-British audience who may be wondering, phrases like 'extremely curious' are intended to be typical examples of polite understatement.

${ }^{149} \mathrm{H}$ Sinzheimer, Grundrüge des Arbeitsrechts (2nd edn 1927) 73 and 209.

150 e.g. RG (11 February 1926) RGZ 113, 33.

151 See CW Guillebaud, The Works Council (1928) 191-196.
} 
reduced. Second, the number of meetings was reduced to one or two a year. Third, the shareholder representatives delegated tasks, by a majority vote, to subcommittees they themselves appointed. The result was that, if indeed the supervisory council had performed a useful monitoring role before, it was severely impaired. It also left the work councils' hopes of gaining insight into business management grievously disappointed.

In 1929, the Reichsgericht leadership changed to Erwin Bumke. ${ }^{152}$ From this point the social state itself was perceived as causing economic problems, and it required constraint. So, the Reichsarbeitsgericht (Empire Labour Court) set about reinterpreting the general scheme of the work council laws. In particular, when representatives faced a choice, said the Reichsarbeitsgericht, under $\$ 66$ they were bound to promote the interests of 'the business' over the interests of employees. For example, in a May 1929 case, a representative who refused to work more than an eight hour day was lawfully dismissed, even though he was in dispute with the employer over working time. He had to put 'the business' first. ${ }^{153}$ In a June 1929 case, a representative who convened a union meeting after a work council meeting could be lawfully summarily dismissed. He had not been putting 'the business' first. 154

This policy shift did not escape a young judge of the Berlin Labour Court. Otto Kahn-Freund had studied in Frankfurt with Sinzheimer. While co-authoring a leading commentary with Georg Flatow and based exhaustive analysis of the post-1929 case law, he contended in a separate article that the Reichsarbeitsgericht was doing no more than reinterpreting the duties of work councillors as being owed to the employer. 'The business' was indistinguishable in practice. At the same time the courts proclaimed, in their jurisprudence on social insurance, the goal of welfare for the isolated worker. Yet workers could not combine to take collective action. Conflict among syndicates of capital and labour were key to social relations, but whenever necessary, conflict would be suppressed in favour of unity and loyalty to a central authority. The social ideal pursued by the court was, concluded Kahn-Freund, fascist. ${ }^{155}$ Later in life, Kahn-Freund said that he had 'made a great mistake', because he 'overestimated the political self-consciousness of the judiciary'. Rather, there was an 'objective factor [...] socially embedded'.156 Fascism was an unconscious culture.

Kahn-Freund was denounced and shunned by the legal academy and trade unions. Perhaps it was because they thought it necessary to keep the appellate courts content. Clemens Nörpel, co-director of the work council centre, at the

\footnotetext{
152 Erwin Bumke was a member of the far right nationalist Deutschnationale Volkspartei. He joined the Nazi Party in 1937, had an illustrious career, and committed suicide in 1945.

${ }^{153}$ RAG (29 May 1929) Bensheimer Sammlung vol 6, no 92, 335.

154 RAG (10 July 1929) BS vol 6, no 77, 320.

155 O Kahn Freund, 'The Social Ideal of the Reich Labour Court - A Critical Examination of the Practice of the Reich Labour Court' (1931) in O Kahn-Freund, R Lewis and J Clark (eds), Labour Law and Politics in the Weimar Republic (Social Science Research Council 1981) ch 3, 108-161.

156 O Kahn-Freund, 'Autobiographische Erinnerungen an die Weimarer Republik. Ein Gespräch mit Wolfgang Luthardt’ [1981] Kritische Justiz 183, 194.
} 
Allgemeine Deutsche Gewerkschaftsbund (ADGB, General German Trade Union Federation) demanded that the article be withdrawn. ${ }^{157}$ Some among the unions did appear to have a great deal to lose. Over the 1920s, officials had displayed similar tendencies to those of supervisory council members as they collected position after position. There were official posts in arbitration panels, on company boards, social insurance boards, or related to politics. A single person frequently had five or six 'jobs'. According to Franz Neumann, a remarkable labour lawyer who was forced to flee from Germany in 1933, there 'was even a trade-union bicycle factory [...] Bound so closely to the existing regime and having become so completely bureaucratic, the unions and the party lost their freedom of action'.158

When the Wall Street Crash came in 1929, as the Smoot-Hawley Tariff Act 1930 triggered a lock down of international trade, as foreign investment was withdrawn, as unemployment rose, and severe depression ensued, the unions were further weakened, especially those which paid unemployment support. Meanwhile, on 18 May 1932, another 'collective agreement' of sorts was being made. Hitler was explaining his intention to abolish the trade unions, as well as political parties, to the Nazi's financial backers, the Freundeskereis der Wirtschaft (Circle of Economic Friends). ${ }^{159}$ Placing the blame on socialism, trade unions and democracy proved to be popular among business. With significant financial support, Hitler's party had climbed dramatically, though it had then fallen, in the four national elections since the start of the financial crisis to the election on 6 November 1932.160 Other conservative parties had initially opposed Hitler. But then as the conservative

\footnotetext{
157 Kahn-Freund [1981] Kritische Justiz 183, 193. See also O Kahn-Freund, 'Letter to Clemens Nörpel' (21 February 1931) Appendix 5, translated in R Lewis and J Clark (ed) Labour Law and Politics in the Weimar Republic (Social Science Research Council 1981).

158 Neumann (1941) 336.

159 See A Schweitzer, 'Business Policy in a Dictatorship' (1964) 38(4) Business History Review 413, 423 424, Wilhelm Keppler, NI-903, 'In May 1932, after I had met with the gentlemen of the Circle of Friends several times, I asked the Führer whether he could not meet with them. The Führer received the business leaders in the small hall of the Kaiserhof on May 18, 1932 [...] The Führer made a short speech, and in it he disclosed, among other things, the following points in his program: abolition of trade unions and abolition of all parties other than the NSDAP. No one raised any objection. On the contrary, these points of the Führer's program met with the fullest approval of the members of the Circle of Friends. They only expressed their apprehension that he would not be able to carry out these excellent ideas.' See also, A Schweitzer, Big Business in the Third Reich (Indiana University Press 1964) 359. Schweitzer's sources are captured documents, from the US post war occupation, of correspondence between business figures and the political regime. They are on file, and ordered by folder, roll and microcopy number (e.g. NI-903) at the National Archives, Washington DC. Schweitzer also refers to originals located at the Bundesarchiv Koblenz (fn 1).

160 Hitler had been released from prison in 1924, and the ban on his public speaking had been lifted in 1927. Beween the 1928 to the 1930 election he had brought the Nazi party from $2.6 \%$ to $18.3 \%$ of the vote. In the Presidential election of March 1932, in which the winner, Hindenburg effectively did not campaign, Hitler won $36.8 \%$ of the vote. The Nazis then won $37.3 \%$ of the vote in the July 1932 election. On 6 November 1932 the Nazis fell sharply to 33.1\%. The next ballot in March 1933 was rigged with terror, the Reichstag was burned, and the crime was falsely blamed on the Communist Party (one of the people accused and tried, Georgi Dimitrov, became the Bulgarian President from 1946 to 1949) with raids on their offices, and Nazi gangs beating up opposing campaigns. In such a climate of fear and violence, it would fail miserably on any criteria of a free election. See, for example, OSCE, Election Observation Handbook (6 $6^{\text {th }}$ edn 2010) 18.
} 
DNVP leader, Franz von Papen, turned on the nationalist Chancellor General von Schleicher, he believed that he might strengthen his own party through a coalition with the Nazis. On 4 January 1933 in the Cologne residence of the banker, Baron Kurt von Schröder, Hitler met with Franz von Papen and agreed to join in government. Franz von Papen believed he could control Hitler because key ministries such as tax and the military were reserved. But Hitler would become Chancellor and get control of the Ministry of Interior. He got the police. ${ }^{161}$ The change took place formally on 30 January.

And from then it was just a tragic matter of time. On 9 February, the three leading employees of the public radio service were dismissed, because they were accused of being communists. Hitler was preparing to hold another vote. A meeting was arranged with the largest business conglomerates on 20 February 1933, led by Gustav Krupp. Hitler lectured that Weimar democracy needed to be destroyed in order for private ownership of the means of production to prevail, and for the capitalist system to be protected. Krupp and the gathering gave unanimous support, and pledged a million Marks for the campaign, set on 6 March 1933.162 The election was characterised by Nazi gangsters beating up opposition campaigners, and imprisonment of the Communist Party leaders who were falsely accused of burning the Reichstag. After this sustained campaign of media intimidation, voter suppression and violence, the Nazis reported themselves winning 44 per cent of the vote. In the hope of not being shut down, the leadership of the trade union movement, the ADGB, feebly stated the Nazi victory was a victory for unions too. ${ }^{163}$ Neumann assessed the situation like this.

Real opposition would have meant strikes, perhaps a general strike and civil war. The movement was neither ideologically nor organizationally prepared for drastic struggle. They could not even fulfil their inner trade-union functions. What little funds remained after the depression were invested in beautiful office buildings, trade-union schools, real estate, building corporations, and printing plants. There was not enough left for their unemployed members. ${ }^{164}$

\footnotetext{
161 Schweitzer (1964) 104-105, 'the Hitler-von Papen government was not only a coalition between the NSDAP and the DNVP; it was also the government of big business and the landowners, because it was their alliance with the Nazis that had persuaded von Hindenburg to appoint Hitler.' 106-7, the conservative parties believed 'the Nazis would be only junior partners [...] The Nazis were given control only over the police, whereas the presidency, the army, and the economic ministries were all in the hands of members of the upper class. Its leaders were convinced that their instruments of power, namely the army, the government purse, and control of the economy, were superior to the power held by the Nazi party and its para-military organizations.'

162 Schweitzer (1964) 105, citing Affadavit of Schacht in NI-406, the 'I.G. Farben Case,' Prosecution, Vol. II. 'After Hitler made his speech, the old Krupp answered Hitler and expressed the unanimous feeling of the industrialist in support of Hitler.' D-203 and 204, Nazi Conspiracy and Aggression, VI, 1080-85. Krupp welcomed Hitler's programme and looked forward to a politically strong and independent state providing conditions for business prosperity. The one million Marks pledged was to be divided between the Nazis, the DNVP and the DVP.

163 R Lewis and J Clark, 'Introduction' in Labour Law and Politics in the Weimar Republic (1981) 28-30.

164 Neumann (1941) 336.
} 
The radio employees had brought their unfair dismissal claim to KahnFreund's court, and on 14 March his decision was released awarding the maximum level of damages. ${ }^{165} \mathrm{He}$ was dismissed for 'political unreliability' on 23 March, and the day after, on the pretext of responding to the Reichstag fire, the Ermächtigungsgesetz 1933 (Enabling Act 1933) was passed, delivering Hitler the power to legislate without Parliament.

It was coming up to May Day, the traditional day of protest and celebration for labour rights. With a craven cowardice, one without parallel, the unions requested participation in the official Nazi rally 'for the honour of creative labour, for the complete incorporation of the working masses into the state'. ${ }^{166}$ 'Then they stood and cheered at the parades. The next day, on the 2 May 1933, the order was given and all the union offices of ADGB members were occupied by the SA and SS. ${ }^{167}$ All union leaders were arrested and imprisoned, and all union assets were seized. 168 'It took exactly thirty minutes for the huge trade-union structure to collapse', wrote Neumann. 'They had become machines without enthusiasm or flexibility. They no longer believed in themselves.'169

\footnotetext{
165 Kahn-Freund [1981] Kritische Justiz 183, 199.

166 Lewis and Clark (1981) 28-30, quote the translated request. Neumann (1941) 337, the unions showed 'more than just cowardice. It was a complete failure to appreciate the real character of National Socialism, and it opened the eyes of the National Socialists. They saw that even the little strength they had attributed to the trade unions was an illusion.'

167 The offices and assets of the Christian trade unions were occupied on 24 June 1933, Neumann (1941) 338.

168 In a roughly sequential order of destruction, the Nazis destroyed (1) the Communist Party (2) the socialist trade unions (3) the Social Democrat Party (4) the Christian trade unions (5) the liberal trade unions (6) all other political parties (7) all independent social clubs and associations (8) anyone with Jewish family (9) homosexuals (10) disabled children (11) business (12) the countries they invaded (13) their own population (14) themselves.

169 Neumann (1941) 337.
} 


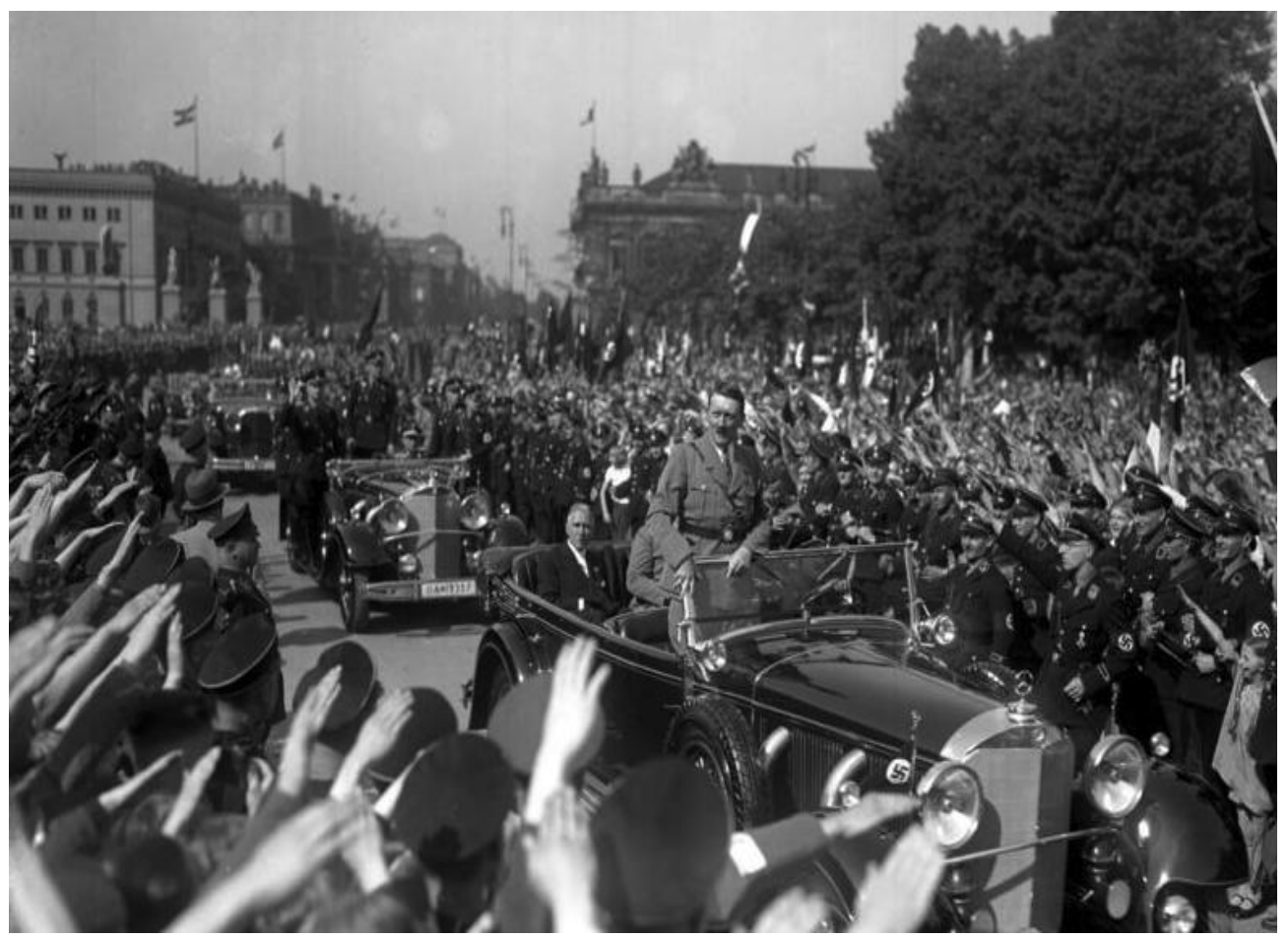

May Day 1933, Unter den Linden, Berlin, near the Lustgarten. Berlin University's Law Faculty is down the street to the left. Union members and officials cheer Hitler. Source: Bundesarchiv Bild 102-15783.

Nobody was safe. Kahn-Freund's house was ransacked by the Schutastaffel (the 'Protection Squad', better known as the SS) and in June he fled to England. Neumann was forced to flee as well. Hugo Sinzheimer escaped to Holland, but was arrested in 1941, and placed in a concentration camp. Friends and family miraculously managed to secure his release, and for the remainder of the war he had no choice but to hide below a roof. Sinzheimer lived to see the military defeat of Nazism, and walked free once more, before he passed away. ${ }^{170}$

How did codetermination develop under the Nazi regime? The basic principle in the new labour law was that everyone would follow the leader of the business, and pledge allegiance to the abstract conception of the undertaking. ${ }^{171}$ On 3 May 1933, a replacement for the trade unions was created, the Deutsche Arbeitsfront (German Labour Front). Every person who worked for a living, eventually including employed and self-employed people alike, was socially compelled to join. ${ }^{172}$ The DAF was a branch of the Nazi party, commanded directly by Hitler. ${ }^{173}$

\footnotetext{
170 K Kubo, Hugo Sinzheimer - Vater des dentschen Arbeitsrechts: eine Biographie (1995) $150 \mathrm{ff.}$

${ }^{171}$ See generally, K Lowenstein, 'Law in the Third Reich' (1936) 45(5) Yale Law Journal 779 and NA Pelcovtis, 'The Social Honor Courts of Nazi Germany' (1938) 53(3) Political Science Quarterly 350. Crucially, the same general duties owed to a business were placed in the Public Companies Act 1937, the Aktiengesetz 1937.

172 Neumann (1941) 341, 'Although there is no legal compulsion to join the Labour Front, the pressure is so strong that it is inadvisable for anyone to stay out. The members must attend meetings, but must not enter into discussion.'

173 Erste Verordnung des Führers und Reichskanzlers über Wesen und Ziel der Deutschen Arbeitsfront vom 24. Oktober 1934.
} 
Its titular leader was Dr Robert Ley, a persistent alcoholic who committed suicide before his Nuremberg trial. A primary task was to create 'understanding' among the 'business leaders' for their 'followers'. In return the followers were to understand the situation and possibilities of the business, by finding the common basis of their 'justified interests' so long as those were in line with Nazi principles. ${ }^{174}$ DAF periodicals were filled with propaganda. Meetings were compulsory, but discussion was absent. ${ }^{175}$ In each workplace, DAF officials acted, in the words of Ley, as 'the soldier-like kernel of the plant community which obeys the Leader blindly. Its motto is "the Leader is always right". 176 The same Fübrerprinzip had prevailed in labour law as it would in company law, with the drafting of the Aktiengesetz 1937 (Public Companies Act 1937). Nazi ideology was not content until it thrust its pathological paranoia onto every association, even clubs for playing chess and collecting stamps. ${ }^{177}$

Formally, codetermination was abolished in 1934.178 Works councils were continued for a short run in a way: the Vertrauensräte, or Councils of Confidence, replaced them and elections were again conducted in 1935. However, Nazi Party nominees were frequently failing to be supported by a majority of workers, and so even these exercises in manufactured approval were scrapped. The positions replaced with appointed 'Trustees of Labour'. ${ }^{179}$ 'The important point', wrote Neumann, is that the individual workers are not members of the federal plant communities. They are solely and exclusively members of the total body, the Labour Front itself.' There could be no belonging by an individual to a group, except the dominant group. There could be no affiliation, except to the nationalised Nazi union. All this was the fruit of that second 'collective agreement'.

It took very little time before business found that they were not benefiting from the abolition of the unions as much as they had expected. Fritz Thyssen, the inheritor of a steel conglomerate and initial Nazi financier, bemoaned the way big

174 DAF Verordnung 1934 \$7, 'Interessenvertretung der Beschäftigen. Die Deutsche Arbeitsfront hat den Arbeitsfrieden dadurch zu sichern, daß bei den Betriebsführern das Verständnis für die berechtigten Ansprüche ihrer Gefolgschaft, bei den Gefolgschaften das Verständnis für die Lage und die Möglichkeiten ihres Betriebes geschaffen wird. Die Deutsche Arbeitsfront hat die Aufgabe, zwischen den berechtigten Interessen aller Beteiligten jenen Ausgleich zu finden, der den nationalsozialistischen Grundsätzen entspricht und die Anzahl der Fälle einschränkt, die den nach dem Gesetz vom 20. Januar 1934 zur Entscheidung allein zuständigen staatlichen Organen zu überweisen sind.'

175 Neumann (1941) 340-341, elaborates five functions as indoctrination, taxation, securing positions for reliable party members, atomising the working classes, and 'the exercise of certain inner trade-union functions.'

176 Neumann (1941) 340.

177 K Robert (a pseudonym), Hitler's Counterfeit Reich (1941) 27-28.

178 Arbeitsordnungsgesetz 1934 (RGBl I, 45).

179 Schweitzer (1964) 368, 'the election of representatives to the councils of confidence in 1935 revealed a significant opposition of workers to the leader-follower arrangement of the Nazi regime. As Bormann reported to Hitler in April of 1935, "not even 50 per cent of the labor force in many plants gave an affirmative vote" for those nominated by the party for membership in the councils.' Schweitzer in turn refers to T Eschenburg, 'Streiflichter zur Geschichte der Wahlen im Dritten Reich' (1955) 3 Vierteljahrshefte für Zeitgeschichte 311, 315. 
business was led on with promises of all kinds, especially to break the strikes and the unions. But then they only found their organisations infiltrated with agents of the Nazi party in the DAF. ${ }^{180}$ In 1941, Gustav Krupp had suffered a stroke, ${ }^{181}$ and the family legacy had passed to Alfried Krupp. At his Nuremburg trial the last Krupp tried to explain how they had seen matters.

The economy required sound or elevated development. The fighting between multiple German political parties and the disorder meant there was no opportunity for building prosperity [...]. We formed the impression that Hitler would bring us healthly development. And in fact he did [...]. We Kruppians have never cared much for ideas. We simply wanted a system that functioned well and gave us the opportunity to work without interference. Politics is not our thing. ${ }^{182}$

If 'a system that functioned well' was the goal, the outcome was infinitely worse. The Nazi state was financially bankrupt by the time it began its campaign to conquer and enslave continental Europe. ${ }^{183}$ If there had been full employment, it was far from full employment in a free society. ${ }^{184}$ Economically, wrote Neumann, the German worker had 'obtained security before the outbreak of the war', but at a horrible cost. It was underwritten by,

the utmost physical insecurity, namely for death [...]. Death in the trenches, death in air raids, death in the factories as a result of physical exhaustion, death in the railroad yards, chemical factories, and the like as a result of a terrific increase in industrial accidents. The connection between economic security and death is not incidental, it is essential... an aggressive imperialist system seeking to transform markets into colonies. ${ }^{185}$

All the while, wrote Kahn-Freund from London, opponents of the Nazis had sounded a "pathetic craving for "legality" and "constitutionalism", which paralysed

\footnotetext{
180 Robert (1941) 35-36. After cooperation with the Nazis Thyssen opposed the war at its outbreak, was captured and imprisoned until the end of the war.

${ }^{181}$ Gustav Krupp was indicted for war crimes at the Nuremberg trials, but did not stand because he had gone senile. He died of syphilis in 1950.

182 Quoted in DM Friz and G Mann, Die Stablgiganten: Alfried Krupp und Berthold Beitz (1990) 33, 'Die Wirtschaft brauchte eine ruhige oder aufwärts steigende Entwicklung. Infolge des Kampfes zwischen den vielen deutschen Parteien und der Unordnung gab es keine Möglichkeit für aufbauende Tätigkeit. [...] Wir hatten den Eindruck, daß Hitler uns solch eine gesunde Entwicklung bescheren würde. Tatsächlich hat er das getan. [...] Wir Kruppianer haben uns nie viel um Ideen gekümmert. Wir wollten nur ein System, das gut funktionierte und das uns eine Gelegenheit gab, ungestört zu arbeiten. Politik ist nicht unsere Sache.' 183 Robert (1941) 41, chs 9 and 10, and 121, 'force and slave economy are not merely separated by an unbridgeable gulf of a free economic system; but the despotic system, in order merely to maintain itself, must fight the free economic system - vastly superior to it technically, commercially and intellectually but relentless, unscrupulous, cunning force.'

184 This was one of the more significant contrasts made in the title of W Beveridge, Full Employment in a Free Society (1944).

185 FL Neumann, 'Labor Mobilization in the National Socialist New Order' (1942) 9(3) Law and Contemporary Problems 544, 546.
} 
the German left and finally led to its downfall'. ${ }^{186}$ This explains part of the profound commitment to union independence, and aversion to legal resolution of labour disputes, which Kahn-Freund would come to call collective laissez-faire. The tiefsitzend, deep-seated, anxiety that Kahn-Freund had acquired, and brought to UK labour law, ${ }^{187}$ was that if labour participation depended on the courts and the state in any way, it could be taken over.

\section{(4) THE RECONSTRUCTION}

After the Second World War, Germany's unions found themselves in a greater position of power relative to the morally bankrupt corporations that supported Nazism. ${ }^{188}$ The reconstruction of the union movement was not as quick as hoped, because it was the Allied policy, for example in the US zone according to General Clay, that unions should be organised from 'the bottom up' and 'should be first local in character and extended no faster than the proven capacity for democratic responsibility and action'. 189 Still, for example near Esslingen in Württemberg, people spontaneously organised Arbeiterausscbüsse (worker committees) which actively identified Nazis, supported welfare and housing, and assisted rebuilding unions. Overall, the US administration saw this as positive.

That unions may serve as a medium for the inculcation of democratic ideals and practices in German life is indicated from the results of opinion polls in Darmstadt. A sampling of union and non-union workers in that city shows union members to be less sympathetic toward Nazi ideas, less inclined to oppose denazification measures, than the population as a whole. Strongest pro-Nazi sentiments were revealed to linger among former white-collar workers. ${ }^{190}$

However, only in April 1946 did the US zone administration allow unions to organise regionally and nationally. ${ }^{191}$ At the same time, the Control Council Law No 22 of 1946 authorised work councils to be formed. This was not compulsory, but rather articles I to III stated that work councils were permitted, without any former DAF or Nazi members, where representatives were elected by democratic

\footnotetext{
186 O Kahn-Freund, 'The Weimar Constitution' (1944) 15 Political Quarterly 235.

187 See E McGaughey, 'British codetermination and the Churchillian Circle' (2014) UCL LRI Working Paper 2/2014.

188 See generally, A Schweitzer, Big Business in the Third Reich (1964). This is not, of course, to suggest that every business was supportive of the government, and on the contrary, remarkable examples of resistance exist, most famously captured in T Keneally, Schindler's Ark (1982).

189 Military Government of Germany, Manpower Division (20 October 1945) No 3, 4.

190 MG of Germany (November 1945) No. 4, 8.

191 MG of Germany (April 20 1946) No. 9, 5, 'Trade unions in the U.S. Zone are entering the second phase of their development. In all major industrial centers local unions mainly of the industrial type have established themselves on democratic foundations and are now reaching out into the wider fields of the Laender.'
} 
methods. ${ }^{192}$ Once formed, article $\mathrm{V}$ listed the various legitimate functions of work councils. ${ }^{193}$ Article VI(3) envisaged the possibility for work council members to attend company supervisory boards, for the purpose of information. It was on this basis that work councils quickly spread again. One of the earliest instances happened to be AEG in Berlin, Rathenau's old firm. ${ }^{194}$ There was no legal coercion to reintroduce codetermination because the Control Council Law No 22 was facilitative, not compulsory. Agreement would need be reached between workers and employers.

Unions were permitted organise without prior Allied authority from October 1946 in the British zone and April 1947 in the American. ${ }^{195}$ Their focus lay squarely upon work councils and board codetermination. German unions had, unlike their UK counterparts, lost as much interest in nationalisation of industry because they themselves were nationalised by the fascist government. The union movement now sought direct participation in the economy, 'socialising power without socialising ownership', with 'distribution of power to the people rather than a concentration of ownership in the state'. ${ }^{196}$ In the coal and steel fields, there was a call for nationalisation at the unions' conference in Bielefeld in 1946. But crucially there was also a call, articulated by union economist Dr Erich Potthoff, for equal representation in management. ${ }^{197}$

The employer side of the industry had been placed under Allied trusteeship. A British civil servant named William Harris-Burland oversaw it, but had put at the head a leading steel manager (never a Nazi member) called Heinrich Dinkelbach. ${ }^{198}$ To implement the policy to demonopolise the industry, ${ }^{199}$ they sought the unions' cooperation. In October 1946, Dinkelbach made a proposal to Hans Böckler, lead representative of the union delegation, that seats on the supervisory board be shared equally. Over a series of conferences, in January 1947, the details were agreed, and the plan put into effect, with five supervisory board representatives each chosen by shareholders and unions, and a chair by the government. ${ }^{200}$ Outside this agreement, there was another three week stoppage by

\footnotetext{
192 Control Council Law No 22 Works Councils (10 April 1946) in Official Gazette of the Control Council for Germany (1945-1946), arts I-III. 43(R498).

193 Control Council Law No 22 (1946) art V, function to protect worker interests in application of collective agreements, health, safety, hiring, dismissals, complaints, improvement of work methods, welfare.

194 Agreement of the Allgemeine Elektrizitäts Gesellschaft Berlin (25 October 1946) referred to by P Fisher, 'Labor Codetermination in Germany' (1951) 18(1) Social Research 449, 455.

195 Control Commission for Germany (British Element), Report for the Month of October 1946, 23. Military Government of Germany, Monthly Report of the Military Governor U.S. Zone (April 1947) No 22, 19.

${ }^{196}$ C Kerr, 'The trade union movement and the redistribution of power in postwar Germany' (1954) 68(4) Quarterly Journal of Economics 535, 535, 544-545 and 555, quoting Viktor Agartz of the DGB. Trade unionists did, however, still nationalisation of 'key industries', see Protokoll Gründungskongress des Deutschen Gewerkschaftsbundes (Köln Bund-Verlag 1950) 318-32.

${ }^{197}$ See his account of the following events in E Potthoff, Der Kampf um die Montan-Mitbestimmung (1957)

198 Dinkelbach was a Catholic, and after his role in the foundation of the steel plan, he was made a Papal count, which it is possible indicated the Vatican's support for codetermination.

199 See Gesetz der Alliierten Hohen Kommission Nr. 27.

200 EF Beal, 'Origins of Codetermination' (1955) 8(4) Industrial and Labor Relations Review 483, 493 495.
} 
workers also in Bielefeld, who demanded codetermination in management: and it was conceded. 201

Thus, after World War Two, both in work councils and in the first instance on the boards of coal and steel firms, codetermination was recreated through collective agreement, precisely as the DGB had aimed to do. ${ }^{202}$ The charge has been made that the British were mainly responsible for it. This view, which comes packaged either as a variant of Dolchstoßlegende by those who oppose codetermination, ${ }^{203}$ or from British people who want to claim credit for everything, ${ }^{204}$ simply does not fit the evidence. First, board representation was driven primarily by the unions' bargaining objectives, to both restore and extend the position in Weimar. Second, it was a German management with whom they bargained.

Third, and most important, the Allied occupation was heavily divided in its views on codetermination. In the British zone, one of the Hamburg legislature's first acts was to introduce codetermination in 1946. The Military Government refused the measure on the ground it would be incompatible with Control Council Law No 22, article VI(3) to have a law. ${ }^{205}$ By 1948 Rheinland-Pfalz and Baden in the French zone, and Württemburg Baden and Hessen in the US zone, had passed similar bills, often fitting into their constitutional provisions that were modelled on Weimar's article 165.206 These efforts were promptly scuttled by the Allied occupiers on the pretext that the British had originally given: Control Council Law No 22 was the policy for now. 207 But also it was said that future changes should be determined democratically by the whole country, when 'the future political structure of Germany has been established and conditions are more stable than at present'. ${ }^{208}$ On 3 September 1948, General Clay unilaterally suspended parts of the new laws in Hessen and Württemburg-Baden, ${ }^{209}$ and they did not come into effect

\footnotetext{
${ }^{201}$ Control Commission for German (British Element), Report for the Month of May 1947, 41.

202 Betriebs-Berater (1946) X 53 (page 14 of issue 10).

203 The 'stab in the back legend' was the view that the First World War was lost because social democrats on the home front betrayed the soldiers in the trenches. There is, apparently, always someone else to blame.

204 e.g. A Bullock, The Life and Times of Ernest Bevin Volume 1: Trade Union Leader 1881-1940 (1960) 435-6, who was attempting to garner support for the plan in the UK.

205 Betriebs-Berater (1946) XIII, 46 (page 14 of the $13^{\text {th }}$ issue).

206 Rheinland-Pfälzischen Landesverordnung über die Errichtung und die Tätigkeit von Betriebsräten vom 15.5.1947 (VOBl. S 258, \$43. Württemburg-Baden Gesetz Nr 726 über die Beteiligung der Arbeitnehmer an der Verwaltung und Gestaltung der Betriebe der Privatwirtschaft vom 18.8.1948, RegBl. 1948 S.136, §24. Verfassung art 22. Betriebsrätegesetz für das Land Hessen vom 31.5.1948, GVBl. 1948 S. 117, \$55. Verfassung art 37. Baden Landesgesetz über die Bildung von Betriebsräten vom 24.9.1948, GVBl. 1948 S.209, \$25.

207 Beal (1955) 8(4) Industrial and Labor Relations Review 483, 493.

208 Military Government of Germany, Manpower, Trade Unions and Working Conditions: Monthly Report of Military Governor U.S. Zone (March 1947 - February 1948) No. 32, 17-18. See also, Control Commission for Germany (British Element), Report for the Quarter 1st January - 31st March, 1951, 41.

209 Betriebs-Berater (1949) 335. This lasted until the successor, John J McCloy, lifted the suspension on 7 April 1950.
} 
elsewhere.210 Yet it was in the British zone that the quickest suppression of codetermination took place. ${ }^{211}$ If the British had not been there, development would have been quicker, and it would have come by law. But that is not how it happened. It happened slowly, and it happened through collective bargaining. Why was there discord among the Allies? Many British staff were from the Ministry of Labour, imbued with Whitley traditions of voluntarism. Many had other views. But it seems plain that in such a large operation, people had different opinions. This left, as the US Military Government stated, 'every right to develop their own relationships with management in collective bargaining. ${ }^{212}$

In 1949 a new constitution, the Grundgesetz. (Basic Law) was completed. It echoed the basic settlement of the Weimar constitution, especially in article 14(2) where it was written again that 'Property carries responsibility'. There was no explicit right to codetermination, but instead the principle became implicit in the constitution's central scheme. Weimar's principles were not torn up, as they had been by the Reichsarbeitsgericht and the Nazis, but were entrenched in article 20, which provided that the new Republic was a 'social state' and article 79(3) which provided that any attempt to amend this constitutional principle would itself be unconstitutional. ${ }^{213}$ A new government was elected, with the Christian Democrat Union led by Konrad Adenauer gaining a majority, and a new Deutsche Gewerkschaftsbund (German Trade Union Federation) was formed, with Hans Böckler becoming the new executive. As the constitution reflected, there was essential, cross-political agreement on the principle of codetermination, not least since the German Catholic Social Conference in 1949 had supported its introduction, and so did the CDU faction in Parliament. ${ }^{214}$

But by late 1950, employer interests were regrouping and the bargaining power of business was growing. The second of the 'Goldilocks conditions' was as strong as ever: the labour movement was united. But the first, of equal bargaining power, was on the wane, simply as a product of business' economic resurgence. When the Economics Minister, Ludwig Erhard, asserted that the collective agreements in the coal and steel industry had no legal status in German law, the

\footnotetext{
210 Note also, Bremen: Ausführungsgesetz zu Art. 47 der Landesverfassung der Freien Hansestadt Bremen vom 10.1.1949 S.7 (BrBRG) without a provision on board involvement. Subsequent laws include Bayern Betriebsrätegesetz vom 15.11.1950, mirroring the Bayern Verfassung art 175. Schleswig-Holstein Betriebsrätegesetz vom 3.5.1950. H Wachenheim, 'German Labor asks Co-management' (1952) 31 Foreign Affairs 310, counted 11 state laws by that time.

211 See also I Turner, 'Codetermination in British-Occupied Germany 1945-1949' in International Handbook of Participation in Organizations (OUP 1989) vol 1, ch 5, 67-8, General Robertson, the leading figure in the Control Commission, said the proposal [by French and Soviets for works council representation on supervisory boards] would 'constitute an unwarranted interference on the part of the works council in the management of an enterprise'.

212 Military Government of Germany, Manpower, Trade Unions and Working Conditions: Monthly Report of Military Governor U.S. Zone (March 1947 - February 1948) No. 32, 18.

213 This view, as with many matters of constitutional interpretation, essentially divides authors who believe that the principle of codetermination is more or less important.

${ }^{214}$ Bundestag Drucksache I/117.
} 
Metalworkers union saw no choice but to ballot for strike action. ${ }^{215}$ It was clear that positive government action was necessary, not to introduce, but to undo codetermination. $^{216}$ Adenauer initially claimed that the use of a strike would be unconstitutional against a democratic government, ${ }^{217}$ a view which Böckler flatly refuted. But in any case Adenauer quickly took up negotiations with the DGB and conceded that a law should be passed. The result was that the MontanMitbestimmungsgesetz 1951 (Mining Codetermination Act 1951) codified the collective bargains for corporate participation in mining that had already been won. ${ }^{218}$ It applied to workplaces with over 1000 staff members, which at the time meant around 105 firms. ${ }^{219}$

While the first codetermination law was in place, was it possible to spread it further? The objective of the DGB, according to its May 1950 platform, was precisely this, by any means, in collective agreements or in law, with parity board codetermination across industry.220 Of course, Eastern Germany was shut off in the Soviet zone. Not surprisingly, in retrospect, it was there that codetermination was suppressed the most. In 1947, Brigadier General Smirnow had declared 'the manager's right to exercise undivided control over the plant' and 'freedom from petty tutelage by works councils'.221 After all, an unfettered right to manage was wholly consistent with Soviet despotism. Like the Nazis, it packed and dominated the unions. 222 The only contrast was propaganda. This required the Constitution of 1949 to proclaim in article 17, that production would be authoritatively codetermined by work councils and unions. ${ }^{223}$ And naturally that was a lie.

Back in the West, employers and politicians were at a broad consensus about worker participation: there was not serious opposition yet, and 'no astute political candidate [could] afford to oppose it'. ${ }^{224}$ More examples of codetermination, going beyond any legal requirement, included the railways in the French zone, copper-

\footnotetext{
215 WH McPherson, 'Codetermination: Germany’ Move toward a New Economy' (1951) 5(1) Industrial and Labor Relations Review 20, 24-25.

216 cf PSJC, 'Managerial Revolution in Western Germany: An Experiment in Co-Determination' (1951) 7(6) World Today 249, 254.

217 Control Commission for Germany (British Element), Report for the Quarter 1st October - 31st December, $1950,105$.

218 Gesetz über die Mitbestimmung der Arbeitnehmer in den Aufsichtsräten und Vorständen der Unternebmen des Bergbaus und der Eisen und Stabl erzeugenden Industrie (21 May 1951) BGBl I S. 347.

219 Biedenkopf Kommission, Bericht der Sachverständigenkommission der Bundesregierung: Mitbestimmung in Unternehmen (1970) 11. Bundestag Drucksache VI/334.

220 Gesetzvorschlag der Deutschen Gewerkschaftsbundes für das Gebiet der Bundesrepublik Deutschland Zur Neuordnung der Deutschen Wirtschaft (May 1950) summarised by Kerr (1954) 68(4) Quarterly Journal of Economics 535, 552.

221 CE Shaw, 'Management-Labor Committees' (1950) 3(2) Industrial and Labor Relations Review 229

222 cf Betriebs-Berater (1948) 472. Note that the author here had not yet appreciated the nature of Soviet dictatorship.

223 Verfassung der Deutschen Demokratischen Republik vom 7.10.1949 GBl. DDR 1949 S. 6.

224 CE Shaw, 'Management-Labor Committees' (1950) 3(2) Industrial and Labor Relations Review 229, 231.
} 
smelting Kupferhütte in Duisburg, or the engineering firm Carl Zeiss in Jena. ${ }^{225}$ The DGB's next goals for collective bargains were federal railways and the whole chemical sector. However, Adenauer's government was reliant on the Free Democrat Party, which was contending that state legislation would be unlawful while the Federal government considered a general law.226 Continuing the collective agreements in steel and mining was one thing, but introducing codetermination in other sectors, where unions were weakening in relative terms, was apparently different.227 The result was that the Betriebsverfassungsgesetr. 1952 (Work Constitution Act 1952) introduced a right to one third of the supervisory board to be employee representatives, and work councils became compulsory, ${ }^{228}$ but all against the votes of the SPD. They resisted because they saw it as a defeat, and strongly objected to particular features, continued from 1920, such as separate voting blocks within work councils for blue and white collar workers.

Perhaps the most significant fact about the 1952 Act was that, if they had to have it, business interests could argue that neither state legislation, nor collective agreement could improve upon its provisions. This was precisely the line adopted as the old forces of reaction re-grouped. Alfred Hueck, who had successfully been 'de-Nazified' (Entnazifiziert) in 1949, but remained an influential company lawyer, contended that the 1952 Act imposed binding standards when it came to board representation.229 Apparently, this argument worked on the ground that the relevant constitutional provisions in the Aktiengesetz 1937 regarding the general meeting and board were compulsory. 230 So, the 1952 Act did not create minimum standards, but was final. This was plainly a false assessment then, 231 and it is plainly is now: any agreement can be reached with those who will make the necessary changes in the corporate structure. ${ }^{232}$ But just enough academic doubt could be raised to dampen union hopes of trying. Hueck's views were significant at the time because he was a close colleague of Hans Carl Nipperdey, who in 1954 was appointed as Bundesarbeitsgericht president. Nipperdey was a complicated figure, or possibly just a banal one, but like Hueck he was clearly implicated in legitimising fascist human rights abuse.233 After the War he had joined the SPD,

225 Betriebs-Berater (1948) 76 on French zone rail. W Cartellieri, 'Die Vorschläge der Duisburger Kupferhütte zum Mitbestimmungsrecht' (30 April 1950) Betriebs-Berater 295.

226 e.g. P Fisher, 'Works Councils in Germany' (March 1951) 41.

227 Kerr (1954) 68(4) Quarterly Journal of Economics 535, 557.

228 Betriebsverfassungsgesetz 1952 BGBl I S. 681.

${ }^{229}$ A Hueck, 'Die Beteiligung der Arbeitnehmer am Aufsichtsrat nach dem Betriebsverfassungsgesetz' (17 Sep 1952) Der Betrieb 781 and A Hueck, 'Erweiterung des Mitbestimmungsrechtes durch Tarifvertrag' (30 November 1952) Betriebs-Berater 925, 928.

230 Aktiengesetz 1937 \$87. He also refers to the Betriebsverfassungsgesetz $1952 \$ 77$.

231 cf B Walter, 'Betriebsverfassungsgesetz und tarifliche Praxis' (1953) Betriebs-Berater 89 and compare G Müller, 'Gegenstand und Verwirklichung des betriebsverfassungsrechtlichen Mitbestimmungs- und Mitwirkungsrechts in personellen Angelegenheiten' (1969) Recht der Arbeit 227. Müller's argument, to the extent that it prevaricates, is also highly flawed.

232 W Däubler, Tarifvertragsgesetz ( $3^{\text {rd }}$ edn 2012) \$1, rn 906 ff. Securing agreement from directors and the shareholder majority will be more practicable in cases where shareholder votes are concentrated. In Germany today, this essentially means securing the votes of the banks.

233 One of Nipperdey's lasting contributions to labour law has been the horizontal application of human rights. He had supported Hans Kelsen against expulsion from Cologne University, but was also a 
and managed to reinvent himself as a friend of labour. But then, the view that law and economics literature has developed - that codetermination only arose through law - was almost entirely upside-down. At every point, in 1933, from 1946, and after 1954 with enough uncertainty in judicial policy, it was always law that was necessary to abolish, suppress and contain codetermination, while collective bargaining had made it.

In this uneasy political balance, two more major codetermination Acts soon passed. First, civil servants acquired slightly more limited rights in the Bundespersonalvertretungsgesetz 1955 (Federal Staff Representation Act 1955). Second, for the mining industries anti-avoidance measures were introduced. Firms subject to the 1951 Act had launched a series of mergers and restructurings. The Mitbestimmungsergänzungsgesetz 1956 (Codetermination Supplement Act 1956) ensured that in subsidiary companies, which were dominated by a parent, employees were still able to vote for the supervisory board of the parent. ${ }^{234}$ In total, the DGB viewed the immediate post-war pattern of codetermination as a disappointment compared to higher hopes. Nevertheless, the basis for a different kind of economic constitution had emerged.235

\section{(5) MODERNISING CODETERMINATION?}

The codetermination laws remained settled until the first SPD government was elected in 1969. Already in 1966, the late CDU Chancellor had formed an investigative commission, chaired by Kurt Biedenkopf, on codetermination reform. It reported under the new Chancellor, Willy Brandt, in 1970. The most important element was its recommendation for 'more employee representatives on the supervisory board [...] with the proviso that shareholder representatives retain a slight majority'. 236 'The report therefore represented a cross party commitment to codetermination, but still on a very specific model. The place of labour representation on the supervisory board had two essential consequences. First,

\footnotetext{
member of the Akademie für Deutsches Recht since its founding in 1933, and he expounded Nazi labour law through subsequent editions of his commentaries, up to A Hueck, HC Nipperdey and R Dietz, Gesetz zur Ordnung der nationalen Arbeit, Kommentar (4th edn 1943). Just one early example of his unemotional assent to human rights violations is his academic approval in RAG 21:191, for a case where an officer of a dissolved trade union was dismissed without notice because otherwise the Nazis could not realise their goals, RAG 44/34 (4 July 1934) 21:188-191 No. 37.

234 Mitbestimmungsergängungsgesetz 1956 BGBl I 707. See also, the Novelle zur Sicherung der Mitbestimmung in Konzernobergesellschaften des Montan-Bereichs 1965, BGBl. I S. 1185; the Mitbestimmungsänderungsgesetz zur befristeten Sicherung der Mitbestimmung in Montan-Unternehmen 1967, BGBl. I S. 1857; and the Mitbestimmungsfortgeltungsgesetz zur befristeten Sicherung der Mitbestimmung in Montan-Unternehmen 1971 BGBl. I S. 1857. The effect of these laws, which were primarily reactions to developments at Mannesmann and Rheinstahl, was to retain codetermination among different group structures and where companies changed production from mining and steel. 235 A Schuchman, 'Economic Rationale of Codetermination' (1957) 10(2) Industrial and Labor Relations Review 270-283.

236 Biedenkopf Kommission, Bericht der Sachverständigenkommission der Bundesregierung: Mitbestimmung in Unternehmen (1970) 96. Bundestag Drucksache VI/334.
} 
because employee voice was not on the executive, the actual determination of the essential direction of a company, and its primary distributive functions (including, for example, signing collective agreements) was shareholder - or more accurately bank ${ }^{237}$ - dominated. A 'slight majority' on the supervisory board would translate into full control when the executive was selected. Any description of German codetermination as involving 'parity' was simply misleading. Second, because employee voice was not in the general meeting, it was far less likely that coalitions among workers and shareholders would be formed, even if shares represented the capital investment of workers.

This model, however, had settled for the time being into consensus. The Mitbestimmungsgesetz 1976 (Codetermination Act 1976) was approved by all major parties, though the influence of the Free Democratic Party, with whom the SPD had a coalition government, was noticeable. After two decades of experience, the FDP was now in favour of codetermination, but insisted that employees, rather than trade unions on workers' behalf, had the right to vote for the employee representatives on the supervisory board. The compromise reached was that in firms with over 2000 employees, employees had a direct vote but could opt to delegate it to their union, and in those with over 8000 it would be delegated by default but employees could opt to exercise the vote themselves. ${ }^{238}$ The chairman of the supervisory board would be appointed by both shareholder votes (again, invariably banks), and employees. If they could not agree after mediation, the shareholder votes could force through a candidate. ${ }^{239}$ The executive should be appointed by a two-thirds majority, but the supervisory board chair had a casting vote to break any deadlock. Thus the only executive member really representative of labour would be one 'Staff Director'. ${ }^{240}$

Despite basic political consensus, Germany's largest banks and corporations claimed the 1976 Act was an unconstitutional violation of the right to property, business freedom and freedom of association. ${ }^{241}$ The Bundesverfassungsgericht (Federal Constitutional Court) rejected the appeal for the key reason that the greater social relevance and use that property had, the more competence the legislature had to regulate its use. ${ }^{242}$ Following the German tradition the judgment

\footnotetext{
${ }^{237}$ Under the Aktiengesetz $1965 \$ 135$ banks are entitled to appropriate the votes of those who buy shares. See F Kübler, 'Comment: On Mark Roe, German Codetermination and German Securities Markets' (1998-1999) 5 Columbia Journal European Law 213. This system was abolished recently in Switzerland by the Eidgenössische Volksinitiative «gegen die Abzockerei» of 2013, which required director remuneration committees to be elected by shareholders, that banks could no longer vote, and that pension funds had to exercise their votes.

238 Mitbestimmungsgesetz 1976 (4 May 1976) BGBl. I S. 1153, §9. See W Streeck, ‘Codetermination: The Fourth Decade' in B Wilpert and A Sorge (eds) International Perspectives on Organizational Democracy (John Wiley 1984).

${ }^{239}$ Mitbestimmungsgesetz $1976 \$ \$ 27$ and 29.

240 Mitbestimmungsgesetz 1976 \$\$31 and 33.

241 According to the Grundgesetz 1949 arts 14, 12 and 9.

242 Bundesverfassungsgericht (1 March 1979) BVerfGE 50, 290, 315-6, after referring to the protection to individual property, 'Dagegen ist die Befugnis des Gesetzgebers zur Inhaltsbestimmung und Schrankenbestimmung um so weiter, je mehr das Eigentumsobjekt in einem sozialen Bezug und einer sozialen Funktion steht.' This appears to echo AA Berle, 'Property, Production and Revolution' (1965)
} 
was written collectively, and an introductory obiter dicta indicated that some members of the court wished to highlight the law still explicitly gave a 'slight predominance' to shareholder representatives. ${ }^{243}$ The intended implication may well have been that a law requiring a majority of employees would be unconstitutional. If so, quite why those who advanced this position believed the predominance was only 'slight' is even less clear than the reasons they might have had for their preferred socio-economic policy.244 It was further held that the interference with freedom of business and association was justified, because the actions of the enterprise were unconstrained, and the enterprise could not in any case be equated with shareholders. ${ }^{245}$

Since 1979, the legitimacy of employee participation in German corporate governance was not seriously questioned. In developing the case law, some of the old themes from Weimar re-emerged, though a different judicial ethic was apparent. For example, it was held to be lawful for the supervisory board to transfer functions to sub-committees and that a requirement of equal representation did not extend to every aspect of work. ${ }^{246}$ However, transfers on crucial questions, such as setting director pay, were not lawful,247 and systematic exclusion of employees from all affairs was also unlawful. ${ }^{248}$ Under an SPD-Green coalition, a new Drittelbeteiligungsgesetz 2004 (One Third Participation Act 2004) recast the rules for companies between 500 and 2000 staff without major changes. Codetermination laws were again reviewed by a new commission, chaired once more by Biedenkopf. It came to no firm conclusions because employer and employee representatives disagreed. ${ }^{249}$ There were still textbooks, for example Christine Windbichler's, which chose to describe German codetermination as an 'unusual, yet less important way to integrate worker interests into the purpose of firms'. ${ }^{250}$ However, such observations appeared increasingly curious, as a majority of EU countries had legislated for codetermination. 251 'As a basic principle', one

65(1) Columbia Law Review 1. See also, F Kübler, W Schmidt and S Simitis, Mitbestimmung als gesetrgebungspolitische Aufgabe (1978).

243 BVerfGE 50, 290, 323, referring to a 'leichtes Übergewicht'.

244 On a proper interpretation, however, the purpose of that section of the court's judgment was merely to delineate the subject matter of the enquiry, and not to prejudge any future law.

245 BVerfGE 50, 290, 352-356.

246 BGHZ 83, 106 (25 February 1982).

${ }^{247}$ BGHZ 89, 48 (14 November 1983).

248 BGHZ 122, 342 (17 May 1993).

249 The work of the Biedenkopf Commission 2005 recommended that board sizes might be reduced and that strict rules might be deviated from in groups. This is the most obvious result of the European Company reincorporations. The German Corporate Governance Code (2010) 4.1.1 squarely places codetermination within its natural structure.

${ }^{250}$ C Windbichler, Gesellschaftsrecht (22 nd edn 2009) 362. Windbichler's observations carry especial weight, given her considerable practical experience as a shareholder representative on the supervisory board between 2001 and 2006 of the former MAN-Roland AG.

251 For the present position, see http://www.worker-participation.eu/. This shows there was no codetermination for 137 million Europeans (Belgium, Cyprus, Estonia, Italy, Latvia, Lithuania, Romania, UK). There was public sector codetermination for 62.1 million (Greece, Malta, Spain, Portugal). There was up to one third codetermination for 87.4 million people (France, Ireland, Luxembourg, Netherlands, 
leading commentary said, 'the participation of employees in the decisions of production or service is today in its essence unchallenged'. ${ }^{252}$ Codetermination was an indelible part of Germany's legal, economic, and social organisation. Popular support was also thorough, as work council elections every four years continued to see enviable turnouts of over 70 per cent. ${ }^{253}$

The contemporary debate turns not on the substance of codetermination, but on its form, particularly with regard to two main developments in EU law. First, when the EU introduced a new company type, the Societas Europaea, it became possible for the management of a German company to bargain with worker representatives to re-incorporate under different rules to the Mitbestimmungsgesetz 1976, including fewer employee board members, or a single tier board.254 In principle the relevant trade union could agree to something worse than it already had, or indeed better, though its bargaining power was plainly buffered by the requirement that in absence of a settlement, the original member state rules applied by default. ${ }^{255}$ Hypothetically, it was also argued that after two years on converting into a Societas Europaea, a company could reincorporate once more and maybe avoid codetermination. The Employee Involvement Directive, article 11 required member states to stop 'misuse' of the corporate form, which was very likely intended to a prevent such a cynical series of reincorporations. Yet the fact that the scope of this provision was not clarified meant proponents of an 'escape from codetermination' could remain hopeful.

Second, it has been debated whether EU freedom of establishment allows companies formed in countries without codetermination, for instance a UK Ltd, to avoid German codetermination laws. This probably depends on how politically adventurous the ECJ judiciary might choose to be because it may seem plain that the member states' public policy exceptions would prevent this. Is EU law being used as a mechanism of transnational codetermination avoidance?256 Or is there a chance for the multi-jurisdictional spread of codetermination?257 Either way, the political dangers to codetermination are perceived as real, and before the 2013 general election this fuelled the call to legislate to extend codetermination to all foreign corporate forms operating in Germany. ${ }^{258}$ The other alternative, it seems

Slovakia). Codetermination under one third for existed for 53 million (Bulgaria, Sweden, Poland, Finland). It was fixed at one third of boards for 36 million (Austria, Czech Republic, Denmark, Hungary, Slovenia). And there was quasi-parity codetermination for the Germans, with 82.5 million people.

252 Däubler, Kittner, Klebe, Wedde, Betriebsverfassungsgesetz. (13th edn 2011) 126.

253 eg Institut der deutschen Wirtschaft Köln, 'Works Council Elections 2010: High Voter Turnout' (2011) Newsletter in English, recording 79\% average turnout in 2010.

254 Although not easy to follow at times, a critical and comprehensive explanation is given by P Davies, 'Workers on the board of the European Company?' (2003) 32 Industrial Law Journal 75.

255 Employee Involvement Directive 2001/86/EC arts 4 and 5.

${ }^{256} \mathrm{H}$ Eidenmüller, A Engert and L Hornuf, 'Incorporating Under European Law: The Societas Europaea as a Vehicle for Legal Arbitrage' (2009) 10 European Business and Organization Law Review 1.

257 This follows from the ability for foreign workers to have a voice in codetermination elections. See also the proposal in M Weiss and A Seifert, 'Der europarechtliche Rahmen für ein "Mitbestimmungserstreckungsgesetz" [2009] 4 ZGR 542-580.

258 SPD, Das Wir Entscheidet. Das Regierungsprogramm 2013-2017 (2013) 22, as well as calling for the threshold for codetermination to be reduced to 1000 , said 'The German right of codetermination must 
clear, would be for workforces to use collective agreements to extend codetermination, wherever the minimum lies. The success of such a strategy would seem now to depend most on the relative bargaining power of the parties.

\section{CONCLUSIONS}

Why does codetermination in Germany? The answer has to be that it originated with collective agreements, freely negotiated between directors and employees. The voluntary foundations of codetermination were evident in 1918 and from 1945 to 1951. Codetermination was collectively bargained. The codetermination bargains forged a social consensus. This consensus was codified into law. The historical evidence sits at odds with the view that sees codetermination as a product of fiat. To the extent that this narrative has supported a view that worker participation in corporate governance is economically inefficient, it must be regarded as wrong. On the contrary, codetermination appeared at the critical historical moments to resolve a significant market failure: it counteracted the inequality of bargaining power between employers and workers.

It is possible that some readers may respond to the argument here by contending that collective agreements are themselves coercive. On this view, the right to strike, which ensures collective bargaining is not just collective begging, is tantamount to duress because it is like holding an employer to ransom. Unions are like cartels, but corporations are just like people. Strikes are coercive, but unemployment is natural. The trouble is, this old view always refused to admit the economic reality that employers can threaten to inflict economic loss by dismissing the workforce, that they usually have more resources to 'hold out' in any economic conflict, ${ }^{259}$ and are thus in a position to impose their intentions on workers throughout the employment relationship. ${ }^{260}$ Unequal wealth distribution between organisations and individuals produces unequal bargaining power, and this significantly imbalances all contract terms, 261 including the terms of worker

also be extended to companies that are in Germany with a foreign legal form and domicile.' cf CDU/CSU, Gemeinsam erfolgreich für Deutschland: Regierungsprogramm 2013-2017 (2013) 15, 'For us social partnership, collective bargaining and codetermination remain essential foundations of our social market economy.' Also, at 25, expressing a commitment to enacting a 'Europa-GmbH' with provisions so that 'national rules concerning codetermination... cannot be circumvented'. This proposed law aims to clarifying existing law, which does appear to require that codetermination applies to all private economic organisations, both German and foreign, operating in Germany. These are enumerated under the Codetermination Act 1976 \$1, namely public and private companies limited by shares, limited partnerships and co-operatives. There is nothing in $\$ 1$, or elsewhere, to suggest this provision applies only to the German forms of those organisations. This is a question of the true construction of the statute.

259 A Smith, The Wealth of Nations (1776) Book I, ch 8, \$12.

260 M Weber, The Theory of Social and Economic Organization (1915, translated 1947) ch I, \$16.

261 This view has now been adopted by the Bundesverfassungsgericht in Bürgschaft (19 October 1993) BVerfGE $\underline{89,214}=$ NJW 1994 36, at paras [56]-[59]. 
participation. These inequalities will damage economic efficiency, because unfairness and unjust enrichment undermine the motivation to work. ${ }^{262}$ Attacks on the right to collective bargaining tread blindly down the road to forced labour, fascism, and ruin. German history is the tormented witness.

Beyond the fact that codetermination arose through collective bargains, voluntarily agreed, the central fallacy in thinking that codetermination rights are akin to fiat is the view that democratic decision making - both in economic organisations and in politics - is itself coercive, and thus inferior to markets. On this view, markets are to be equated with freedom for everyone to choose, and when this is so, the state is thought to be a neutral umpire. In the utopia of a nexus of contracts, everyone is equal. But just as the codetermination bargains were made when markets had become genuinely more equal, so the democratic change it inspired brought a less coercive economy, because people at work were no longer subordinated to the Herr im Haus. It would go too far in the other direction to say markets operate through no more than 'blind coercion', 263 but it is true that there can be no unified theory of contracts. ${ }^{264}$ The contract that leads people to join an enterprise has always differed in a fundamental respect to the contract for exchange of goods. To meet the changing needs, the enterprise will invariably retain the power to unilaterally vary the quid pro quo in the relationship over time, ${ }^{265}$ while the benefits production are always realised centrally, and then distributed. Generally speaking, the best parties to determine the terms of an exchange are those privy to an agreement, rather than a court or the state. And indeed, in enterprises where the corporate form has the right to direct, and to appropriate the benefits of production from capital and labour, ${ }^{266}$ the best parties to determine how wages, dividends or executive pay are distributed will generally be those who institute the enterprise by investing their capital and labour. ${ }^{267}$ When democratic laws began to codify codetermination, they codified, not some fake theory, but the lessons of experience in how to secure genuine freedom and autonomy in association.

\footnotetext{
262 On these economic principles, see Smith (1776) Book I, ch 8, $\$ \$ 43$ and 47, Book V, ch 1, \$107. A Marshall, Principles of Economics (3rd edn 1895) Book VI, ch 4, 649. AA Berle and GC Means, The Modern Corporation and Private Property (1932) 114. For discussion of empirical evidence, E McGaughey, 'Behavioural economics and labour law' (2014) LSE Working Paper Series No. 20/2014.

$263 \mathrm{~S}$ Webb and B Webb, Industrial Democracy (1920) Part III, ch 2, 687-8.

${ }^{264}$ F Kessler, 'Contracts of Adhesion - Some Thoughts About Freedom of Contract' (1943) 43(5) Columbia Law Review 629, 636.

265 e.g. Deborah Lawrie-Blum v Land Baden-Württemberg (1986) Case 66/85, [1986] ECR 2121 at [17]. Naturally, within the concept of direction is the possibility for the employer to vary the terms of work, even, in effect, reducing the worker's wage.

266 See BGB $\$ 950$, where the meaning of 'Hersteller' is interpreted as the owner of property (ie the corporation) not the worker who improves the property. For shareholders, appropriation is an automatic consequence of the corporate form.

${ }^{267} \mathrm{nb}$ this assumes that the general rules of competition and regulation protect consumers and the public, which is typically not so in enterprises that are subject to sector-specific regulation or have habitually been candidates for public ownership.
} 